\title{
Aerosol chemical composition at Cabauw, The Netherlands as observed in two intensive periods in May 2008 and March 2009
}

\author{
A. A. Mensah ${ }^{1, *}$, R. Holzinger ${ }^{2}$, R. Otjes ${ }^{3}$, A. Trimborn ${ }^{1}$, Th. F. Mentel ${ }^{1}$, H. ten Brink ${ }^{3}$, B. Henzing ${ }^{4}$, and \\ A. Kiendler-Scharr ${ }^{1}$ \\ ${ }^{1}$ Institut für Energie- und Klimaforschung: Troposphäre (IEK 8), Forschungszentrum Jülich GmbH, Jülich, Germany \\ ${ }^{2}$ Institute for Marine and Atmospheric research Utrecht (IMAU), Utrecht, The Netherlands \\ ${ }^{3}$ Energy research Centre of The Netherlands (ECN), Petten, The Netherlands \\ ${ }^{4}$ Netherlands Organisation for Applied Scientific Research (TNO), Utrecht, The Netherlands \\ *now at: Institute of Atmospheric and Climate Science (IAC), ETH Zurich, Zurich, Switzerland
}

Correspondence to: A. A. Mensah (amewu.mensah@env.ethz.ch) and A. Kiendler-Scharr (a.kiendler-scharr@fz-juelich.de)

Received: 5 September 2011 - Published in Atmos. Chem. Phys. Discuss.: 12 October 2011

Revised: 28 April 2012 - Accepted: 2 May 2012 - Published: 30 May 2012

\begin{abstract}
Observations of aerosol chemical composition in Cabauw, the Netherlands, are presented for two intensive measurement periods in May 2008 and March 2009. Submicron aerosol chemical composition was measured by an Aerodyne Aerosol Mass Spectrometer (AMS) and is compared to observations from aerosol size distribution measurements as well as composition measurements with a Monitor for AeRosol and GAses (MARGA) based instrument and a Thermal-Desorption Proton-Transfer-Reaction MassSpectrometer (TD-PTR-MS). An overview of the data is presented and the data quality is discussed. In May 2008 enhanced pollution was observed with organics contributing $40 \%$ to the $\mathrm{PM}_{1}$ mass. In contrast the observed average mass loading was lower in March 2009 and a dominance of ammonium nitrate $(42 \%)$ was observed. The semi-volatile nature of ammonium nitrate is evident in the diurnal cycles with maximum concentrations observed in the morning hours in May 2008 and little diurnal variation observed in March 2009. Size dependent composition data from AMS measurements are presented and show a dominance of organics in the size range below $200 \mathrm{~nm}$. A higher O:C ratio of the organics is observed for May 2008 than for March 2009. Together with the time series of individual tracer ions this shows the dominance of OOA over HOA in May 2008.
\end{abstract}

\section{Introduction}

Aerosol particles directly and indirectly affect the global climate. Depending on their optical properties, particles can scatter or absorb long and short wave radiation. This can have cooling or heating effects on the atmosphere and has thus a direct impact on the radiation balance of the Earth (e.g. global dimming, Nazarenko and Menon, 2005; Ramanathan et al., 2007; Romanou et al., 2007). Aerosol particles also exhibit a range of indirect effects in acting as cloud condensation nuclei $(\mathrm{CCN})$. Changes in particle number concentration and size distribution alter cloud albedo (Norris and Wild, 2007) and can cause suppression or enhancement of rain (Nober et al., 2003; Tao et al., 2007; Phillips et al., 2002). The IPCC report 2007 identifies aerosol particles as the major uncertainty in the prediction of future climatic conditions (IPCC, 2007). Aerosol particles are providing the surface for heterogeneous reactions, thus affect the atmospheric lifetime of atmospheric trace constituents (Dentener and Crutzen, 1993). Furthermore, aerosol particles control the visibility and are associated with health hazards such as increased cardiopulmonary (Moolgavkar et al., 1994) or lung cancer mortality (Pope et al., 2002). Apart from water, the major constituents found in atmospheric aerosol particles are sulfate, nitrate, ammonium, minerals, black carbon (BC) and organic components often referred to as organic matter (OM) (Rogge et al., 1993). The fractional abundance of the 
individual constituents is strongly dependent on the particles origin and processing during their atmospheric lifetime.

Ammonium nitrate is a major component of the $\mathrm{PM}_{1}$ mass in polluted regions of Europe where reductions in sulfur dioxide emissions have reduced the occurrence of ammonium sulfate (Monks et al., 2009). Also the ubiquity of organic components in boundary layer aerosol particles is well documented (Zhang et al., 2007). Recently Jimenez et al. (2009) pointed out that atmospheric aging lowers the organic aerosol volatility and thus enhances the persistence of the particulate organic aerosol fraction and their hygroscopic properties (Jimenez et al., 2009; Morgan et al., 2010b). The inorganic particulate aerosol is well characterized in Central Europe in general and especially at the measurement location of the campaigns presented in this paper (Schaap et al., 2011; Weijers et al., 2011; ten Brink et al., 2007, 2009).

Here we present an overview of the aerosol composition as measured in two intensive observation periods at Cabauw, the Netherlands. The measurements were linked to the intensive observation periods of the European Integrated Project on Aerosol Cloud Climate and Air Quality interactions (EUCAARI) (Kulmala et al., 2009) and activities of the European Monitoring and Evaluation Programme (EMEP, http://www.emep.int/). Previous work on this data set has focused on the aerosol direct effect (Roelofs et al., 2010; Morgan et al., 2010a) and showed that the high fraction of ammonium nitrate observed in May 2008 largely impacts the aerosol optical thickness (Roelofs et al., 2010). It was shown that due to its semi-volatile nature maximum concentrations of ammonium nitrate are observed at the top of the boundary layer (Morgan et al., 2010a). The height profile needs to be taken into account when modelling the aerosol direct effects. We focus on the comparison of different instruments that measured the inorganic aerosol components in May 2008. Aerosol particle mass spectrometric data is compared to the results obtained by Monitor for AeRosol and GAses (MARGA) and Thermal-Desorption Proton-TransferReaction Mass-Spectrometry (TD-PTR-MS) measurements. We show that the inorganic particulate aerosol mass concentrations derived by the different approaches are in good agreement with each other. Diurnal patterns of particulate inorganic and organic aerosol are discussed and an overview of the concentrations observed in the two campaigns is presented. Beside analysis of the inorganic particulate matter, we extend the analysis by investigating the composition of the organic particulate phase by high resolution time of flight mass spectrometry. In particular the $\mathrm{O} / \mathrm{C}$ ratio and individual tracer ions are used to track OOA and HOA in both observation periods. To our knowledge, this is the first time that online analysis of the organic particulate aerosol phase is reported for that measurement location.

\section{Experimental}

\subsection{CESAR Tower}

As part of EMEP and the EUCAARI project, several intensive observations periods were defined during which the aerosol particles chemical composition was characterized by aerosol mass spectrometry (AMS) at a number of field sites throughout Europe (Kulmala et al., 2011). An Aerodyne High Resolution Time of Flight AMS (HR-ToF AMS, hereafter referred to as AMS) was operated at the Cabauw Experimental Site for Atmospheric Research (CESAR), The Netherlands, during two of these intensive observation periods. The first campaign (Intensive Measurement Period At Cabauw Tower, IMPACT) took place in May 2008, the second in March 2009. The CESAR observatory $\left(51^{\circ} 57^{\prime} \mathrm{N}\right.$, $4^{\circ} 54^{\prime} \mathrm{E},-0.7 \mathrm{~m}$ a.s.1) is located at a rural site in the center of the Netherlands, about $20 \mathrm{~km}$ south-west of Utrecht and $50 \mathrm{~km}$ south of Amsterdam. The measurement site is representative for North-West Europe and features continental and maritime conditions, depending on the wind direction. The plain geography of the Netherlands and especially in the area of Cabauw reduces ambiguities in terms of air parcel convection and turbulences. The CESAR observatory is run by the Royal Netherlands Meteorological Institute (KNMI), De Bilt, The Netherlands. The site features a $213 \mathrm{~m}$ high tower equipped with standard measurement devices for outside and dew point temperature, and wind direction and speed at $200 \mathrm{~m}, 140 \mathrm{~m}, 80 \mathrm{~m}, 40 \mathrm{~m}, 20 \mathrm{~m}, 10 \mathrm{~m}$, and $2 \mathrm{~m}$ height. Beside this, precipitation, cloud cover and height, radiation and a range of remote sensing, flux and concentration measurements of Green House Gases (GHG) are continuously performed (Russchenberg et al., 2005).

\subsection{AMS}

The AMS was located in the tower basement, sampling from an aerosol sampling line, which was shared with other aerosol instrumentation. The inlet system consisted of four parts: (a) $4 \mathrm{PM}_{10}$ size selective inlets, (b) a Nafion drying system that dried the aerosol stream to or below $40 \%$ relative humidity, (c) a $60 \mathrm{~m}$ stainless steel pipe, and d) a manifold that splits the flow to a variable suite of instruments. Instruments sampled their flow from the manifold using separate pumps to adjust the required flow for proper operation. The total flow sustained in the $60 \mathrm{~m}$ inlet pipe was kept at about $601 \mathrm{~min}^{-1}$, which was the highest flow that warranted laminar flow $(R e \approx 2000)$. Excess air was drawn through the sampling heads and the pipe to assure optimal operation of the $\mathrm{PM}_{10}$ inlets and to keep the flow in the pipe at $601 \mathrm{~min}^{-1}$ even if the suit of instruments used less. Whenever an instrument was added or removed from the manifold, the excess air and flows to the other instruments were checked and adjusted when needed. The entire distance between tower inlet at $60 \mathrm{~m}$ height and AMS inlet was about $70 \mathrm{~m}$. The AMS 
was connected to the sampling manifold by $3 \mathrm{~m}$ stainless steel tubing with an inner diameter of $4 \mathrm{~mm}$. The flow of $680 \mathrm{ml} \mathrm{min}^{-1}$ between the manifold and the AMS inlet was achieved by parallel sampling of the AMS $\left(80 \mathrm{ml} \mathrm{min}^{-1}\right)$ and an Ultrafine Condensational Particle Counter (UCPC, TSI 3786, $600 \mathrm{ml} \mathrm{min}^{-1}$ ).

The working principles of the Aerodyne Aerosol Mass Spectrometer (AMS) were described in detail elsewhere (Canagaratna et al., 2007; Jayne et al., 2000; Jimenez et al., 2003). A brief summary of the modes of operation and calibrations performed during the campaigns follows here.

The AMS allows the mass spectrometric online investigation of aerosol particle composition after substantial reduction of the gas phase. The AMS can be separated into four sections: an aerodynamic lens as inlet, a differentially pumped vacuum particle sizing chamber, a vaporization/ionization region and a mass spectrometer (MS). An aerosol stream of $80 \mathrm{ml} \mathrm{min}^{-1}$ passes through a Liu type aerodynamic lens (Liu et al., 1995a, b). The lens reduces the gas phase to particle phase concentration by a factor of $10^{7}$. This gas phase reduction is a key feature since gaseous nitrogen alone has a concentration of $950 \times 10^{6} \mu \mathrm{g} \mathrm{m}^{-3}$ in the air and particulate aerosol concentrations range from a few micrograms per meters cubed in remote areas like Hyytiälä, FI (Zhang et al., 2007) to about $100 \mu \mathrm{g} \mathrm{m}^{-3}$ in polluted areas like Mexico City, MX (Aiken et al., 2009). The lens has an almost $100 \%$ transmission efficiency for particles between $60 \mathrm{~nm}$ and $600 \mathrm{~nm}$. Particles in the size ranges of $30 \mathrm{~nm}$ to $70 \mathrm{~nm}$ and $500 \mathrm{~nm}$ to $2500 \mathrm{~nm}$ are still substantially transmitted, with a $50 \%$ transmission efficiency for particles of $1 \mu \mathrm{m}$ (Jayne et al., 2000; Zhang et al., 2004). Hence, the AMS is referred to as $\mathrm{PM}_{1}$ instrument (Canagaratna et al., 2007). The particle sizing is achieved in a differentially pumped particle sizing chamber by measuring the particles time of flight $(\mathrm{PToF})$ between entering the chamber and detection. After passing through the PToF chamber the particle beam strikes the vaporizer. In general, the vaporizer is operated at approximately $600^{\circ}$ causing the non-refractory components of the particles to flash evaporate on the surface (Jayne et al., 2000). The evaporated molecules are ionized by $70 \mathrm{eV}$ electron impact (EI) and are then extracted into the MS for compositional analysis. The HR-ToF mass spectrometer acquires a full mass spectrum in one ion extraction, which occurs every $30 \mu$ s in V-mode and every $50 \mu$ s in W-mode. Vand $\mathrm{W}$-mode refer to the flight path of the ions within the MS. V-mode is a single reflection flight path $(1.3 \mathrm{~m})$ and Wmode is a triple reflection flight path $(2.9 \mathrm{~m})$ with resolving powers of about 2000 and 4000, respectively (DeCarlo et al., 2006). This allows for a clear separation of different ions of the same nominal mass such as $\mathrm{C}_{2} \mathrm{H}_{3} \mathrm{O}^{+}$and $\mathrm{C}_{3} \mathrm{H}_{7}^{+}$on mass to charge ratio $\mathrm{m} / \mathrm{z} 43$. In the so called MS mode of operation mass spectral information is collected over the integral aerosol size distribution. In the PToF mode of operation size dependent compositional data is acquired.
For quantitative measurements with the AMS the ionization efficiency (IE) needs to be determined by a calibration with ammonium nitrate particles (Drewnick et al., 2004; Jayne et al., 2000). In the standard calibration procedure as performed here dried and size selected ammonium nitrate particles are measured with the AMS and a condensational particle counter (CPC) in parallel. Taking the bulk density of ammonium nitrate, the size, and the number of the particles, the total mass of aerosol particles introduced into the AMS is calculated. This value is compared to the detected ion signal of the mass spectrometer. A scaling factor is introduced to link the amount of molecules introduced into the AMS with the ion count per molecule detected by the AMS. The scaling factor, the so called IE, is in general at the order of $10^{-6}$ ions/molecule. The ammonium nitrate calibration allows for the determination of other aerosol compounds in terms of nitrate equivalent mass. The actual mass of the compound of interest can be determined, when the compounds specific ionization efficiency is known. In practice, ionization efficiencies relative to the ionization efficiency of nitrate $\left(\mathrm{IE}_{\mathrm{NO}_{3}}\right)$ are used. These ionization efficiencies are called relative ionization efficiencies (RIE). E.g., the RIE of ammonium $\left(\mathrm{RIE}_{\mathrm{NH}_{4}}\right)$, which is determined during the standard IE calibration, is generally about 4 .

Another quantity that needs to be determined for quantitative measurements with the AMS is the Collection Efficiency (CE, Huffman et al., 2005). The CE is a unit less quantity, which accounts for the difference between aerosol mass entering the instrument and the detected mass. Since the CE is composition dependent (Matthew et al., 2008; Crosier et al., 2007), its determination will be explained in detail in the upcoming section Aerosol Particle Composition (3.2.1).

In both observation periods, the aerosol stream was dried by two Nafion dryers at the inlet at $60 \mathrm{~m}$ height. Therefore, RH values measured in the sampling line do not reflect ambient RH. The RH time series were incorporated into the AMS data analysis to apply a time dependent correction for the contribution of gas phase water $(\mathrm{RH})$ to the total water signal detected by the AMS. A relative ionization efficiency of water $\left(\mathrm{RIE}_{\mathrm{H}_{2} \mathrm{O}}\right)$ of 2 as determined by Mensah et al. (2011) was applied for determination of the residual particulate water. Size calibrations were performed through measurements of the particle time of flight of polystyrene latex particles (PSL, Duke Scientific Corporation, Palo Alto CA) of defined sizes.

At Cabauw, the AMS was operated in alternation mode, switching between V-mode (MS, and PToF mode) and Wmode (MS mode only) regularly. The vaporizer temperature was set to about $580^{\circ}$ throughout both sampling periods. The AMS was run on remote control to enable permanent control of the instrument performance. Particle size and ionization efficiency calibrations were performed once a week. Regular measurements with a High Efficiency Particulate Air (HEPA) filter in line were performed to determine the gas phase background signal. Data was collected with a time resolution of $5 \mathrm{~min}$. 
The data acquired with the AMS will be compared to data acquired by several other collocated aerosol measurement instruments. In the following short descriptions of a Scanning Mobility Particle Sizer (SMPS, TSI 3034), two Monitor for AeRosol and GAses (MARGA, ten Brink et al., 2007) instruments, and a Thermal-Desorption Proton-Transfer-Reaction Mass-Spectrometer (TD-PTR-MS, Holzinger et al., 2010b) will be given.

\subsection{SMPS}

Likewise the AMS, the Scanning Mobility Particle Sizer (SMPS) was located in the basement and sampled from the common aerosol inlet line. It was operated with 5 min time resolution and the particle number size distributions covering the diameter range from about $10 \mathrm{~nm}$ to $470 \mathrm{~nm}$ were measured with a log-equidistant resolution of 32 size bins per decade in both campaigns.

The mobility size spectrometer (e.g. ten Brink et al., 1983) consists of a sequential set-up of an impactor, neutralizer, differential mobility analyzer (DMA) and a condensation particle counter (CPC). In the DMA, aerosol particles are classified according to their electrical mobility. The analyzer consists of a cylinder with a negatively charged rod at the center. Only aerosols in a narrow range of mobility exit through the output slit, where they enter the CPC, which determines the particle concentration of that size. Before entering the DMA, aerosols are brought to a bipolar charge equilibrium using a ${ }^{85} \mathrm{Kr}$ bipolar charger (neutralizer). In charge equilibrium, the fraction of particles with a single elementary charge is known for all sizes (Wiedensohler, 1988). An impactor upstream of the DMA removes particles larger than the upper size limit of the mobility spectrometer and allows for correction of multiple charged particles with same mobility as the singly charged particles that are to be counted.

The operated SMPS is a modified version of a commercially available instrument (TSI 3034). To ensure reliable measurement data that is comparable to other European measurement data, the technical standards for mobility size spectrometers developed within the EUSAAR project are followed (Wiedensohler et al., 2012). Moreover, the SMPS participated in a series of three intercomparison workshops conducted between 2006 and 2009 at the WCCAP (World Calibration Centre for Aerosol Physics) facilities in Leipzig (Wiedensohler et al., 2012). At the workshops the particle counting efficiency of the CPC used here was experimentally determined and the inversion routine, necessary for converting measured mobility distributions into final particle number size distributions taking into account the bipolar charge distribution as well as the DMA transfer function, was compared to different commercial and custom-programmed inversion routines to insure optimal performance of the SMPS system.

\subsection{MARGA}

The two MARGA instruments sampled at a separate inlet at $4 \mathrm{~m}$ height and collected aerosol at ambient RH and temperature. The MARGA is a combination of a Wet Annular Denuder (WAD) followed by a Steam Jet Aerosol Collector (SJAC, Slanina et al., 2001) to facilitate the chemical online analysis of water soluble gases and particulate aerosol components at the same time (Trebs et al., 2004). Details of the calibrations, quality assurance and data analysis procedures routinely performed for MARGA are described in Trebs et al. (2004). Here we give only a summary of the specific sampling strategy for the Cabauw site. The instrument can be run with different inlets to confine the particle size range. The MARGA-2S was deployed as the standard Applikon instrument (http://www.metrohm-applikon. com/Products/MARGA.html). The MARGA-2S was in operation at the Cabauw site as part of the Dutch Beleid Ondersteunend Project (BOP) program for over a year (September 2007-October 2008). It measured both the $\mathrm{PM}_{10}$ and $\mathrm{PM}_{2.5}$ fraction. This was accomplished by sampling the ambient air with a Teflon coated $\mathrm{PM}_{10}$ impactor at $2 \mathrm{~m}^{3} \mathrm{~h}^{-1}$. A polyethene tube carried the sample air to an indoor splitter. The outdoor length of $2 \mathrm{~m}$ was surrounded by a fan driven outdoor airflow to prevent wall interactions. Indoors, the sample lines were insulated for the same purpose. After the iso-kinetic split the two lines were connected to the two MARGA sampling boxes. In one of the lines a Teflon coated $\mathrm{PM}_{2.5}$ cyclone was inserted. The Marga- $2 \mathrm{~S}$ was serviced on a weekly basis. Both sample flows were calibrated. The analytical part, the anion and cation ion chromatography (IC), was continuously calibrated by a traceable internal $\mathrm{LiBr}$ standard solution. Generally the sum of the $\mathrm{PM}_{2.5}$ ions represents $50 \%$ of the $\mathrm{PM}_{10}$ mass fraction. The measured ion concentrations compared well with filter measurements (Schaap et al., 2011).

The MARGA-Sizer (ten Brink et al., 2007) was located beside the MARGA-2S and sampled through the same inlet. It was operated throughout the year 2008 as part of the Dutch Besluit Subsidies Investeringen Kennisinfrastructuur BSIK program. The MARGA-Sizer sampled ambient air through a $1 \mathrm{~m}^{3} \mathrm{~h}^{-1}$ Teflon coated $\mathrm{PM}_{2.5}$ impactor at $301 \mathrm{~min}^{-1}$, which represents about the particle fraction with diameters smaller than $2 \mu \mathrm{m}$. The outdoor inlet was surrounded by the same outdoor airflow as used for the MARGA-2S. Key difference between the MARGA-2S and MARGA-Sizer is a preseparator of parallel mounted impactors for size classification defining the measurement range of the particles by different cut off sizes. During May 2008 the MARGA- Sizer was operated with 5 Moudi impactor stages of the following cut off sizes: $0.18 \mu \mathrm{m}, 0.32 \mu \mathrm{m}, 0.56 \mu \mathrm{m}, 1.00 \mu \mathrm{m}$, and $2.00 \mu \mathrm{m}$. The cut off characteristics of the Moudi stages were checked with mono disperse Latex spheres prior to the May 2008 IMPACT campaign. Additionally to the five impactor inlets, an inlet equipped with a particle filter was 
used to perform blank measurements and determine the background concentration of the compounds. Measurements through the different size classes were alternated, resulting in a semi-continuous measurement but gaining insights to the size distribution of the individual species. In the standard $2 \mathrm{~h}$ cycle the blank was analyzed twice, while each impactor stage, the direct connection and the denuder (gas phase measurements) only once. The time coverage per fraction was thus $12.5 \%$. Due to the low concentrations in the sample solutions for the smallest fractions the ICs were equipped with concentrator columns instead of the standard injection loops. Calibration and servicing of the MARGA-Sizer was the same as for the MARGA-2S. The MARGA-Sizer output was normalized by a factor 1.8 to match with the MARGA$2 \mathrm{~S}$ results. The cause of deviation remained unexplained and implications will be discussed below.

\subsection{TD-PTR-MS}

The TD-PTR-MS instrument was located inside the building next to the MARGA instruments. Aerosol was sampled from the roof at a height of $5 \mathrm{~m}$ above the ground through a $10 \mathrm{~m}$ long non-insulated copper tube with an inner diameter of $4 \mathrm{~mm}$. The system consists of a modified commercial PTR-MS (Ionicon Inc., Innsbruck, Austria, Hansel et al., 1995; Lindinger et al., 1998) which is equipped with both a gas and an aerosol inlet. Since detailed descriptions can be found in Holzinger et al. (2010a, b) only a brief description follows. The centerpiece of the aerosol inlet is a Collection-Thermal-Desorption (CTD) cell (Williams et al., 2006, Aerosol Dynamics, Berkeley, CA, USA), which collects ambient particles in the $0.07 \mu \mathrm{m}$ to $2.00 \mu \mathrm{m}$ size range at an air sample flow rate of $11 \mathrm{~min}^{-1}$, and allows for gradual thermal desorption of the collected sample into the PTRMS system. Particle collection is achieved by humidificationaided impaction onto the stainless steel collection surface using a sonic jet impactor. Humidification was needed to reduce particle rebound. Additionally, the CTD cell contains an auxiliary injection port for the manual introduction of liquid standards by means of a syringe. The transfer lines and the PTR-MS drift tube were operated at elevated temperatures of $200^{\circ}$ to avoid re-condensation of evaporated particulate aerosol compounds. A measurement cycle of the TD-PTRMS system is as follows: While the PTR-MS is connected to the gas phase inlet, ambient air is pulled through the CTD cell and the aerosol particles are collected on a sharp point in the CTD cell. Due to the high operating temperature of the PTR-MS drift tube and inlet lines a significant fraction of the aerosol particles evaporate, so that in the gas-phase channel the combined signal of gas phase and condensed-phase organics is detected. After aerosol collection a small flow of $10 \mathrm{ml} \mathrm{min}^{-1}$ to $12 \mathrm{ml} \mathrm{min}^{-1}$ of nitrogen carrier gas transports $100 \%$ of the compounds evaporating from the CTD cell directly into the PTR-MS. The temperature of the CTD cell is ramped from ambient temperatures to $350^{\circ}$, which takes about $15 \mathrm{~min}$ at a ramping rate of $25^{\circ} \mathrm{min}^{-1}$. After a cool down period of $10 \mathrm{~min}$ to $15 \mathrm{~min}$ a new collection cycle can be started. The operation including valve switching and heating/cooling is automated and therefore the system is capable of continuous measurements over extended periods of time.

The instrument was equipped with a quadrupole mass filter which recorded full mass spectra in the mass range of $20 \mathrm{Da}$ to $219 \mathrm{Da}$ at a scanning speed of $0.2 \mathrm{~s} / \mathrm{mass}$ unit, so a full mass scan was completed every $40 \mathrm{~s}$. The TD-PTRMS detects all species with the same sensitivity and signals of the measured aerosol species can be directly related to a mass concentration without calibration. While Holzinger et al. (2010a) pointed out that in principle all desorbable organic aerosol compounds should be detectable with this method, reservations hold with respect to possible fragmentation during proton transfer or thermal dissociation on the CTD cell which can produce simple structures such as $\mathrm{CO}_{2}$, $\mathrm{CO}$ or $\mathrm{NO}_{2}$ that are not detected by PTR-MS. If not otherwise mentioned, concentrations of individual aerosol species have been calculated according to the procedure outlined in Holzinger et al. (2010b).

\section{Results and discussion}

\subsection{Measurement conditions}

Key meteorological parameters are shown in Fig. 1. The top graph (Fig. 1a) presents data from May 2008 and the bottom graph (Fig. 1b) data from March 2009. The top panels in both graphs show the wind direction. As a guidance of the eye, northerly wind directions are colored in blue, southerlies in red, and easterly and westerly wind directions in green. Ambient temperature $(T)$ and the relative humidity (RH) at $40 \mathrm{~m}$ height are given in the second upper panel. Further, the aerosol composition as observed with the AMS is shown in the lower parts of the graphs. Particle mass loadings of organics (Org, green), nitrate $\left(\mathrm{NO}_{3}\right.$, blue), sulfate $\left(\mathrm{SO}_{4}\right.$, red), ammonium $\left(\mathrm{NH}_{4}\right.$, orange), and chloride $(\mathrm{Cl}$, pink) are shown in the second lowest panels, as well as the total nonrefractory mass loading (black), i.e. the sum of these species. The contributions of the individual species to the total mass are shown as a function of time in the bottom panels of Fig. 1a and b. Gaps in the time series are due to instrument maintenance, calibrations, filter measurements, or instrument failure.

The 2008 measurement period was dominated by easterly and south-easterly wind directions (top panel in Fig. 1a) transporting air masses from Eastern and Central Europe to the measurement site. An overview of the synoptic situation over Europe through the campaign is given by Hamburger et al. (2011). From 17 to 20 May northerly winds from the North Sea prevailed, transporting low mass loadings of aerosol particles $\left(<5 \mu \mathrm{g} \mathrm{m}^{-3}\right)$ due to precipitation scavenging. This time period is referred to as scavenged background 
situation from here on. Though not reflected in the local wind profile, the meteorological background was dominated by long range transport of Sahara dust from North Africa from 23 May on (Roelofs et al., 2010), from here on referred to as Sahara dust period. The particulate aerosol mass loading reached maximum concentrations of more than $30 \mu \mathrm{g} \mathrm{m}^{-3}$ during this period. As opposed to 2008 , the measurement period in 2009 was dominated by westerly winds (top panel in Fig. 1b), almost uniformly covering the entire range from South to North. Only on 29 February and in the period from 17 to 21 March easterly winds, predominantly from northeasterly directions, were present.

As mentioned above, the aerosol stream was dried by two Nafion driers in both campaigns. Since the temperature in the basement was generally higher than the ambient temperature, the positive temperature gradient caused a further reduction of the RH within the sampling line. In May 2008, the ambient temperature and $\mathrm{RH}$ ranged from $6.5^{\circ}$ to $25.2^{\circ}$ and $24.5 \%$ to $99.8 \%$, respectively, with average values of $15.5^{\circ}$ and $62.8 \%$, respectively. In the same time period, the temperature at the AMS inlet ranged from $22.7^{\circ}$ to $29.4^{\circ}$ with an average of $26.5^{\circ}$ and the $\mathrm{RH}$ ranged from $12.7 \%$ to $42.2 \%$ with an average of $23.1 \%$. This indicates, that the temperature was generally higher and the $\mathrm{RH}$ lower in the basement accompanied by a considerably reduced spread in the values. Since the measurement period in 2009 took place in early spring, recorded temperatures were lower and RH higher compared to the summer campaign in 2008. In March 2009, the average ambient temperature was only $7.0^{\circ}$ $\left.\left(0.7 \leq T{ }^{\circ}\right] \leq 11.2\right)$ and the average $\mathrm{RH}$ as high as $77.6 \%$ $(31.9 \leq \mathrm{RH}[\%] \leq 99.2)$. As opposed to 2008 , RH and temperature data were not available at the AMS inlet.

\subsection{Aerosol particle composition}

The temporal evolution of the total particle mass loading as well as the individual species as shown in the middle panel in Fig. 1a resulted in an average mass loading of $10.21 \mu \mathrm{g} \mathrm{m}^{-3}$ in spring 2008. The chemical composition of the aerosol particles was generally dominated by organics (bottom panel in Fig. 1a), accounting for $40 \%$ of the total mass averaged over the measurement period (Fig. 2a). The second dominant contributor to the particles composition was nitrate $(26 \%)$, which was distinctly anti-correlated to sulfate $(18 \%)$. The scavenged background situation during mid of May was characterized by an average mass loading of only $3.69 \mu \mathrm{g} \mathrm{m}^{-3}$ accompanied by a high fractional abundance of sulfate and a very low fractional abundance of nitrate. In contrast to that, the Sahara dust period had an average mass loading of $14.35 \mu \mathrm{g} \mathrm{m}^{-3}$ with maximum concentrations of almost $40 \mu \mathrm{g} \mathrm{m}^{-3}$. This period, especially from 25 to 28 May was characterized by decreasing organic and increasing nitrate contributions. In March 2009, the dominance of nitrate $(42 \%)$ and organics ( $22 \%$ ) contribution to the average non-refractory particulate aerosol composition (bottom
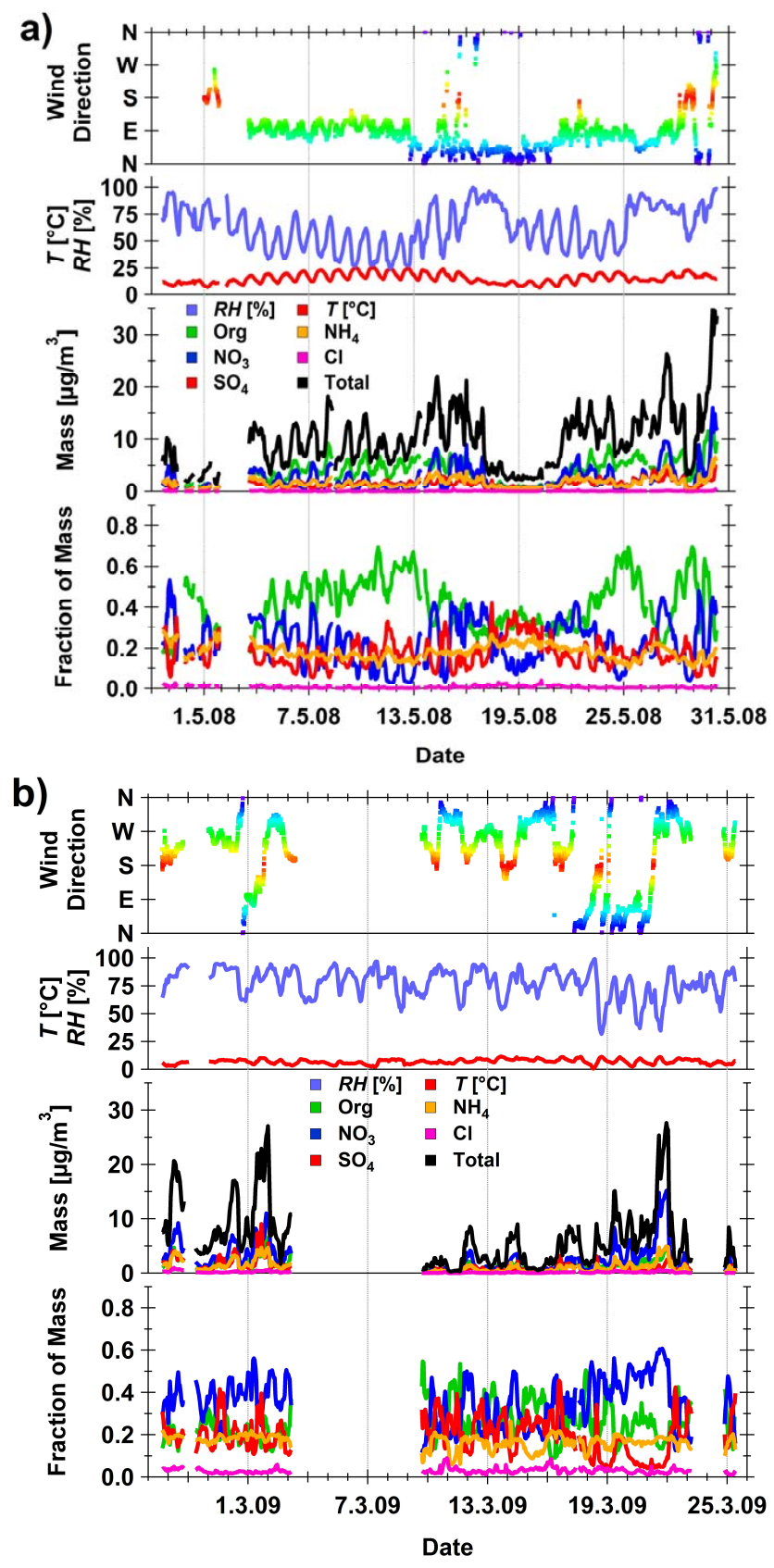

Fig. 1. Campaign overviews of aerosol chemical composition in May 2008 (a) and March 2009 (b). Mass concentrations (second lowest panel) and relative contributions (lowest panel) are shown for total AMS measured mass (black), ammonium (orange), nitrate (blue), sulfate (red), organics (green), and chloride (purple). The ambient temperature and RH in the second upper panel as well as the wind direction in the most upper panel are given in both graphs. As a guidance of the eye, northerly wind directions are colored in blue, southerlies in red, and easterly and westerly wind directions in green.

panel in Figs. 1b and Fig. 2b), is interchanged compared to May 2008. Furthermore, an average mass loading of only 

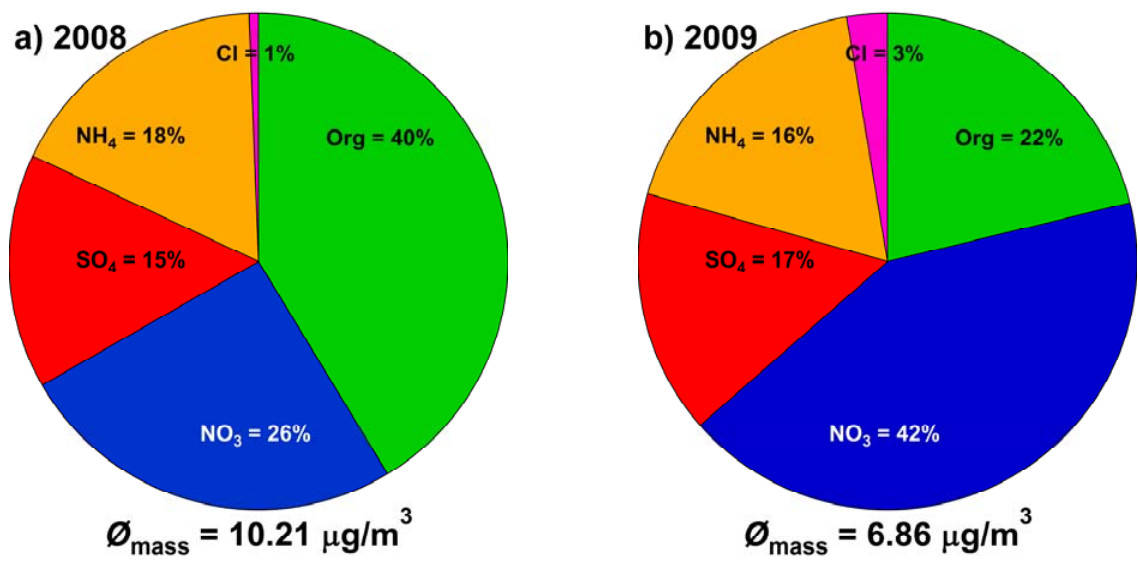

Fig. 2. Mean aerosol composition in May 2008 (left) and March 2009 (right). While the aerosol chemical composition is dominated by organics $(40 \%)$ in May 2008, the main fraction is composed of nitrate (42\%) in March 2009. The average mass loading was $10.21 \mu \mathrm{g} \mathrm{m}^{-3}$ in May 2008 and $6.86 \mu \mathrm{g} \mathrm{m}^{-3}$ in March 2009.

$6.86 \mu \mathrm{g} \mathrm{m}^{-3}$ was measured. Since westerly winds dominated during March 2009, the aerosol particles had a significantly shorter time over land and therefore a limited time to take up organic species. This fact in combination with the generally reduced biogenic activity and reduced photochemistry in winter time can explain the reduced organic contribution to the average particle composition in March 2009 compared to May 2008. The average fractional abundances of sulfate, ammonium and chloride show only minor differences between 2008 and 2009. To calculate the residual particulate water content detected by the AMS the $\mathrm{RIE}_{\mathrm{H}_{2} \mathrm{O}}$ (Mensah et al., 2010) and the RH in the basement in 2008 and in the pipe in 2009 , respectively, was taken into consideration in data analysis. The average residual particulate water was $0.67 \mu \mathrm{g} \mathrm{m}^{-3}$ in 2008 and $0.37 \mu \mathrm{g} \mathrm{m}^{-3}$ in 2009 corresponding to $6.6 \%$ and $5.5 \%$ of the average particulate mass reported for 2008 and 2009 , respectively.

In 2008 the AMS measured ammonium concentration exceeded the mass needed for neutralization of nitrate and sulfate up to $20 \%$. Artifacts from data analysis are unlikely since special attention was paid in terms of possible interferences from gas phase ammonia and relative ionization efficiency of ammonium determined by repeated ionization efficiency calibrations. Unusually high ammonia concentrations measured at CESAR tower in previous campaigns were assigned to agricultural activities nearby (Schaap et al., 2011; Weijers et al., 2011). We speculate that our observed excess ammonium has agricultural sources, since high concentrations of nitrogen containing compounds such as ammonia and amines are known not only to be in the manure but also to evaporate in significantly amounts (Rotz, 2004). Particles containing oxalic acid can take up significant amounts of ammonia from the gas phase under laboratory conditions, which then can be detected as particulate ammonium by the AMS (Mensah et al., 2011). As discussed below, there is evidence of substantial contribution of highly oxidized organic compounds, such as organic acids to the particulate aerosol mass in May 2008. Further characterization of the measurement location is needed for a final explanation of this observation, since a chicken farm is located only about $600 \mathrm{~m}$ north west of the CESAR tower.

\subsubsection{Determination of $\mathrm{CE}$ and comparison of AMS with SMPS}

The determination of the absolute mass loading in the AMS requires the knowledge of the CE. Dry and solid particles, e.g. particles with a high sulfate mass fraction, tend to bounce off the vaporizer without being evaporated, i.e., substantial amounts of the introduced particulate mass will not be detected in the MS. That means in reverse, the ratio of introduced to detected amount is favored for wet or waxy particles, e.g. particles with a high nitrate mass fraction. Laboratory studies show that the CE can range from 0.3 for ammonium sulfate dominated to 1.0 for nitrate dominated internally mixed particles (Matthew et al., 2008). A CE value of 0.5 was determined in numerous field campaigns (Canagaratna et al., 2007 and references therein). To evaluate if this value is also appropriate for these specific measurements, the mass loadings determined by the AMS are compared to other measurements. Comparisons are generally performed for the total particle mass loading (Quinn et al., 2006) or specific components, e.g. sulfate (Drewnick et al., 2004). The upper panel of Fig. 3 shows the ratio of AMS nitrate to the particulate MARGA-Sizer nitrate of the $1 \mu \mathrm{m}$ channel $\left(\mathrm{AMS}_{\mathrm{NO}_{3}} / \mathrm{MARGA}_{\left.\mathrm{NO}_{3}, 1.00\right)}\right)$ in blue and the according ratio for sulfate $\left(\mathrm{AMS}_{\mathrm{SO}_{4}} / \mathrm{MARGA}_{\mathrm{SO}_{4}, 1.00}\right)$ in red. In both panels an inflection of the mass ratios at a particulate nitrate mass fraction $\mathrm{MF}_{\mathrm{NO}_{3}}$ of about 0.3 can be seen. $\mathrm{MF}_{\mathrm{NO}_{3}}$ is defined as the particulate nitrate mass divided by the total particulate mass. This inflection is mass and time independent and 
is controlled mainly by the nitrate mass fraction. The lower panel of Fig. 3 shows the ratio of the total mass detected by the AMS to the mass derived from SMPS measurements (AMS/SMPS, black squares) versus the $\left(\mathrm{MF}_{\mathrm{NO}_{3}}\right)$. The inflection at $\mathrm{MF}_{\mathrm{NO}_{3}}=0.3$ can also be seen in this comparison. This seems to be a general behavior across Europe based on other AMS measurements performed at other locations during that campaign (Nemitz et al., 2012). The particulate aerosol mass was determined from the measured SMPS number distributions. To compare the mass loading of the AMS to measurements of the SMPS two things need to be considered concerning the different size cut offs of AMS and SMPS (Kleinman et al., 2008). First, the AMS has an almost $100 \%$ transmission efficiency of particles only between $\sim 60 \mathrm{~nm}$ to $\sim 600 \mathrm{~nm}$. There is a steep decrease in transmission efficiency for particles smaller and larger than this size range. Already particles of $700 \mathrm{~nm}$ show significantly decreased transmission efficiency of only $67 \%$ in laboratory experiments (Jayne et al., 2000). Second, the size range of the AMS is given as aerodynamic diameter $\left(d_{\mathrm{va}}\right)$. To compare to the geometric diameter $\left(d_{\text {geo }}\right)$ reported by the SMPS, the particle density needs to be taken into account. In a rough calculation assuming spherical particles and an average particle density of $1.5 \mathrm{~g} \mathrm{~cm}^{-3}$, a $d_{\mathrm{va}}$ of $600 \mathrm{~nm}$ corresponds to a $d_{\text {geo }}$ of only $400 \mathrm{~nm}$. In the actual calculation, the following steps were performed. Each number distribution was transferred into a volume distribution under the assumption of spherical particles. In each measurement interval the fractional abundance of the individual species determined by the AMS was used to calculate the particle density. Densities of dry $\mathrm{NH}_{4} \mathrm{NO}_{3}$ $\left(1.72 \mathrm{~g} \mathrm{~cm}^{-3}\right)$ and $\left(\mathrm{NH}_{4}\right)_{2} \mathrm{SO}_{4}\left(1.77 \mathrm{~g} \mathrm{~cm}^{-3}\right)$ were used as well as a density of $1.40 \mathrm{~g} \mathrm{~cm}^{-3}$ for organics (Hallquist et al., 2009). The chloride detected in the AMS needs to flash evaporate at the vaporizer temperature of about $600^{\circ}$. The probability that this chloride origins from an inorganic salt is very small. We set the density of the chloride fraction to $1.00 \mathrm{~g} \mathrm{~cm}^{-3}$ and expect only a minor impact on the average particle density in view of the low fractional abundance of $1 \%$ and $3 \%$, respectively, in the two measurement periods. The mass was then calculated by combination of the volume and the density information.

To account for the known fact of a composition dependent CE of the AMS (Crosier et al., 2007), especially the dependence on $\mathrm{MF}_{\mathrm{NO}_{3}}$, an empirical function was generated. A constant $\mathrm{CE}$ of 0.5 was applied to all measurements with a $\mathrm{MF}_{\mathrm{NO}_{3}}$ below 0.3 (Eq. 1a), which corresponds to the value found in other field campaigns with dry, sulfate dominated aerosol particles (Allan et al., 2004). Atmospheric nitrate is dominated by ammonium nitrate and laboratory experiments show a CE of 1.0 for pure ammonium nitrate particles (Matthew et al., 2008), in which the $\mathrm{MF}_{\mathrm{NO}_{3}}$ is 0.78 . This fact is reflected in equation $1 \mathrm{~b}$. To account for the increasing $\mathrm{CE}$ of particles with increasing nitrate fraction, the CE of particles with a $\mathrm{MF}_{\mathrm{NO}_{3}}$ above 0.3 and below 0.78 was calculated according to Eq. (1c):

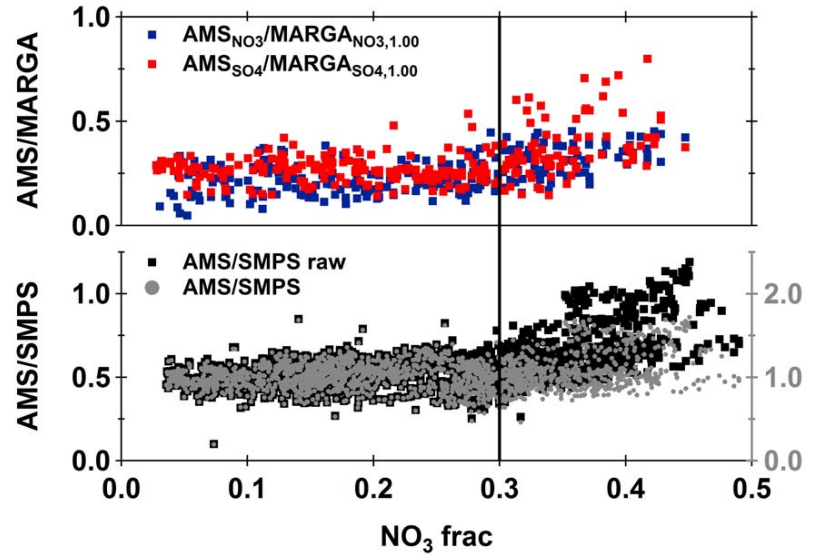

Fig. 3. Lower panel: ratio of raw (black squares, left axis) and CE corrected (grey dots, right axis) AMS total mass to SMPS derived aerosol particle mass as a function of nitrate mass fraction $\left(\mathrm{MF}_{\mathrm{NO}_{3}}\right)$ in the particles. Top panel: raw AMS/MARGA-Sizer $(1.00 \mu \mathrm{m}) \mathrm{ni}-$ trate (blue) and sulfate (red) mass ratios. Note that the CE of the AMS shows a dependence on the aerosol nitrate fraction with increasing nitrate fraction leading to increasing collection efficiency.

$\mathrm{CE}=0.5$ for $\mathrm{MF}_{\mathrm{NO}_{3}}<0.3$

$\mathrm{CE}=1.0$ for $\mathrm{MF}_{\mathrm{NO}_{3}}=0.78$

$\mathrm{CE}=0.1875+1.0417 \times \mathrm{MF}_{\mathrm{NO}_{3}}$ for $0.3 \leq \mathrm{MF}_{\mathrm{NO}_{3}}<0.78(1 \mathrm{c})$

These equations reflect the general behavior of the CE across Europe and is also given by Nemitz et al. (2012). The change of the AMS/SMPS mass ratio after application of this CE is shown by the grey dots in the lower panel of Fig. 3 (right axis). The magnitude of the standard deviation of the AMS/SMPS ratio is reduced from $24 \%$ to $18 \%$ and the ratio has a value of $1.06 \pm 0.20$ after application of the $\mathrm{CE}$ to the AMS data.

For further comparison time series of the total particulate mass loading of the AMS (black) and the mass loading derived from these SMPS measurements (red) are shown in Fig. 4. from 14 May 2008 to End of May 2008. The measurements show very good quantitative and qualitative agreement, since even small temporal loading variations are visible in both time series. Correlating the SMPS derived mass to the total AMS mass results in a slope of $0.89\left(R^{2}=0.86\right)$ even when the Sahara dust event is included. High mass loadings of more than $30 \mathrm{\mu g} \mathrm{m}^{-3}$ were measured during the Sahara dust event. 
Table 1. Correlation of the $0.56 \mu \mathrm{m}$ and the $1.00 \mu \mathrm{m}$ channel of the MARGA-Sizer to AMS loadings of $\mathrm{NO}_{3}, \mathrm{SO}_{4}, \mathrm{NH}_{4}$ and $\mathrm{Cl}$. Presented are the slopes and one standard deviation of a linear regression over the entire measurement period in May 2008. The coefficient of determination $\left(R^{2}\right)$ is given in parenthesis.

\begin{tabular}{rrrrr}
\hline & $\mathrm{NO}_{3}$ & $\mathrm{SO}_{4}$ & $\mathrm{NH}_{4}$ & $\mathrm{Cl}$ \\
\hline $0.56 \mu \mathrm{m}$ & $1.03 \pm 0.02(0.70)$ & $1.12 \pm 0.03(0.22)$ & $0.73 \pm 0.02(0.37)$ & $0.72 \pm 0.03(0.49)$ \\
$1.00 \mu \mathrm{m}$ & $1.91 \pm 0.03(0.82)$ & $1.81 \pm 0.03(0.69)$ & $1.32 \pm 0.02(0.72)$ & $1.30 \pm 0.04(0.68)$ \\
\hline
\end{tabular}

Middlebrook et al. (2011) evaluated the impact of composition of the particle on the CE in greater detail. Similar to our results they found a constant $\mathrm{CE}$ for particles with a $\mathrm{MF}_{\mathrm{NO}_{3}} \leq 0.31$ and an increasing $\mathrm{CE}$ with higher $\mathrm{MF}_{\mathrm{NO}_{3}}$. The constant CE was determined to be 0.45 , which can be considered relatively low compared to the minimum/average value found in other field measurements (Canagaratna et al., 2007). Overall, the application of Eq. (6) in Middlebrook (2011) to our data would result in higher AMS mass loadings, which would increase the discrepancy to the SMPS derived mass loading.

\subsubsection{Comparison of inorganic composition from AMS and MARGA-Sizer}

The AMS data are further compared to measurements obtained with a MARGA-Sizer, which was available in May 2008 (Fig. 5). Here, we only present the comparison to data acquired with the $560 \mathrm{~nm}$ sampling inlet of the MARGA-Sizer. Figure 5 is separated into four panels presenting from top to bottom the particulate chloride $(\mathrm{Cl})$, ammonium $\left(\mathrm{NH}_{4}\right)$, sulfate $\left(\mathrm{SO}_{4}\right)$ and nitrate $\left(\mathrm{NO}_{3}\right)$ concentrations measured by AMS (colored lines) and MARGA-Sizer (black lines). The respective time series follow each other very well and good quantitative agreement is achieved. Since the AMS is considered a $\mathrm{PM}_{1}$ instrument best quantitative agreement was expected with the data obtained through the $1.00 \mu \mathrm{m}$ channel. However, the measurement results of the $1.00 \mu \mathrm{m}$ channel are on average a factor of 1.6 higher than the AMS results, which is in the range of the scaling factor of 1.8 applied to the MARGA-Sizer data equivalence with the standard MARGA-2S. Correlations of the individual species for AMS and the $560 \mathrm{~nm}$ channel of the MARGASizer show ratios ranging from 0.73 and 0.72 for ammonium and chloride, respectively, to 1.03 and 1.12 for nitrate and sulfate, respectively. It should be noted that even though the quantitative agreement of AMS and MARGA-Sizer was best for the $560 \mathrm{~nm}$ channel, the coefficients of determination $\left(R^{2}\right)$ were higher for the comparison of AMS with the $1 \mu \mathrm{m}$ channel (see Table 1). This indicates that indeed the variation of the concentrations observed by the AMS was better fetched by the $1 \mu \mathrm{m}$ channel. The difference in absolute mass concentration between the AMS and the $1 \mu \mathrm{m}$ channel of the MARGA-Sizer could be due to different sample positions for the AMS (60 m) and MARGA-Sizer $(4 \mathrm{~m})$, since the observed mass will depend on the vertical distribution of

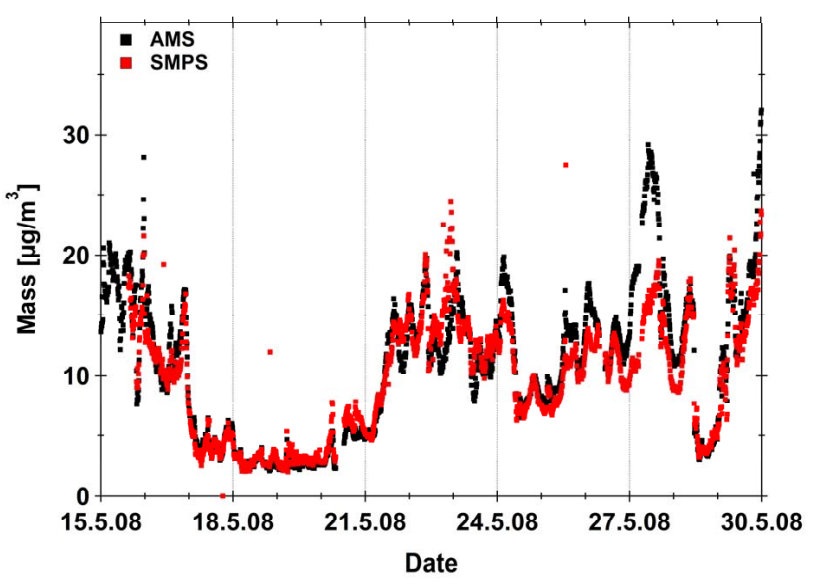

Fig. 4. Time series of AMS total mass and mass derived from SMPS measurements in 2008.

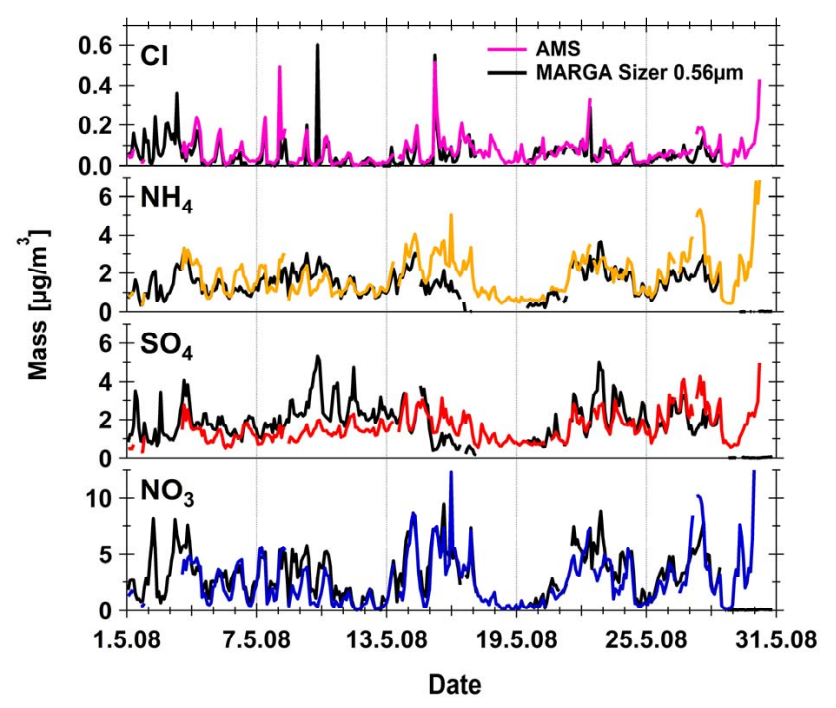

Fig. 5. Comparison of AMS chemical composition with MARGA sizer data for the May 2008 intensive campaign. AMS data are compared to MARGA $0.56 \mu \mathrm{m}$ channel with good agreement in terms of both absolute mass concentration and relative trends.

species as well as on the losses within the sampling line. Considering the instrumental accuracies and limitations due to different sampling locations AMS and MARGA-Sizer show a qualitatively good agreement. 


\subsubsection{Comparison of nitrate and organics from AMS and TD-PTR-MS}

During May 2008, the TD-PTR-MS was applied for measurements of individual components in the $\mathrm{PM}_{2}$ range. The single highest signal was detected at $m / z 46$, which is attributed to $\mathrm{NO}_{2}^{+}$. Note that unambiguous ion composition assignment is hindered here by the use of a Quadurpole MS. Concentrations were calculated using a molecular weight of $62 \mathrm{~g} \mathrm{~mole}^{-1}\left(\mathrm{NO}_{3}\right)$ and a default reaction rate constant for proton transfer of $0.85 \times 10^{-9} \mathrm{~cm}^{3} \mathrm{~s}^{-1}$ molecule ${ }^{1}$. The detection of ammonium nitrate and the accuracy of the parameters were confirmed in laboratory experiments. Figure 6 (lower panel) shows that the TD-PTR-MS derived nitrate corresponds quite well to the AMS nitrate $\left(R^{2}=0.60\right)$. It is interesting to note that the built-up of high night time concentrations in the period 9-13 May was not observed with the TD-PTR-MS. The reason for this is not known at this point. The top panel in Figure 6 compares the total organic signal measured with the TD-PTR-MS (all aerosol species except $\mathrm{m} / \mathrm{z} 46$ ) and the particulate organic fraction detected in the AMS. In the period 9 May to 16 May the TD-PTR-MS total organic signal was about $30 \%$ of the AMS organic concentration. This fraction is lower than previously published values of comparisons to other AMS measurements, however, in the period 17 May to 20 May the TD-PTR-MS total organic signal was about $85 \%$ of AMS organic concentration. During this period very clean conditions prevailed and the high fraction detected with the TD-PTR-MS is in agreement with data from the Mt. Sonnblick observatory (Holzinger et al., 2010a). The increase in detection sensitivity of the TDPTR-MS might be due to changes in the composition of the aerosol particles. The fractional contribution of organics is significantly decreased at that time, which is most probably accompanied by an increase in the hygroscopicity of the aerosol particles. Since particle collection is achieved by humidification-aided impaction, an increased hygroscopicity of the particles could result in an increased collection efficiency. The organic contribution increases again after the 21 May. Unfortunately, no TD-PTR-MS data is available after that time to investigate this hypothesis in greater detail. A relatively high correlation of the TD-PTR-MS signal at $\mathrm{m} / z, 149$ with AMS chloride is achieved in the time from 15 May midnight to 17 May midnight $\left(R^{2}=0.75\right)$ as shown in Fig. 7 (lower panel). This time period includes a distinct peak in chloride concentration that was not only captured by AMS and TD-PTR-MS but also by the water soluble chloride detecting MARGA-Sizer (compare top panel in Fig. 5). The ratio of signals detected at $\mathrm{m} / \mathrm{z} 149, \mathrm{~m} / \mathrm{z} 150$ and $\mathrm{m} / \mathrm{z} 151 \mathrm{sug}$ gests that organic species with one chloride atom such as $\mathrm{C}_{6} \mathrm{H}_{9} \mathrm{ClO}_{2}$ could cause the majority of the signal. However, since the TD-PTR-MS was operated with a Quadrupole MS, we cannot exclude the contribution of several other species to the signal detected at $m / z 149$. Utilizing the high resolution capabilities of the AMS, we could identify a mass peak

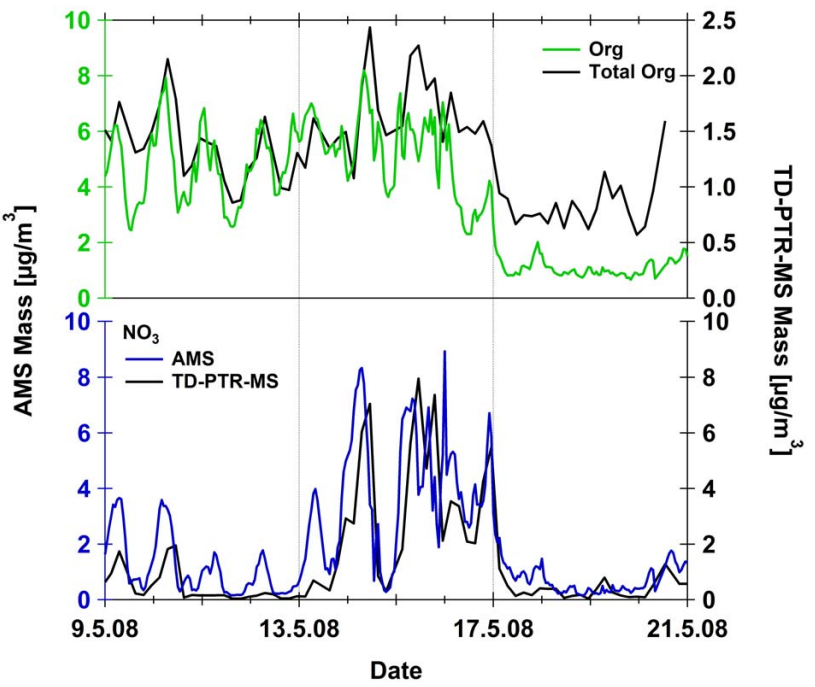

Fig. 6. Comparison of AMS to TD-PTR-MS results. Lower panel: AMS nitrate (blue, left axis) and TD-PTR-MS nitrate $(\mathrm{m} / \mathrm{z}, 46$, black, right axis). Upper panel: AMS organic (green, left axis) and TDPTR-MS total organic (black, right axis).

at $m / z 148.029\left(\mathrm{C}_{6} \mathrm{H}_{9} \mathrm{ClO}_{2}\right)$ that is indicative of an organic chloride source (red line in upper panel of Fig. 7). The same temporal behavior of the corresponding isotope $\left(\mathrm{C}_{6} \mathrm{H}_{9}^{37} \mathrm{ClO}_{2}\right.$, $\mathrm{m} / \mathrm{z}$ 150.026) can be found. The ratio of these two signal reflects the isotopic ratio of ${ }^{35} \mathrm{Cl} /{ }^{37} \mathrm{Cl}$ when no constrains are applied within the analysis software. Therefore, these peaks can be considered real, even though they account for only a minor fraction of the total chloride containing high resolution signal $(<1 \%)$. On the one hand, this time trace does not show high correlation to the time trace of the TD-PTR-MS signal on $\mathrm{m} / \mathrm{z} 149$. On the other hand, peaks simultaneous in time for aliphatic organic ions detected on mass to charge ratios $m / z 43, m / z 55$, and $m / z 57$ can be found, which will be discussed in further detail in Sect. 3.5.1. These findings support the expectation that AMS chloride originates from organic compounds as discussed earlier.

\subsection{Chemical size distribution}

Campaign averages of chemically resolved size distributions as measured by the AMS at CESAR tower in 2008 (dashed lines) and 2009 (solid lines) are shown in Fig. 8. The mode diameter of the total mass (black line, panel a) is about $500 \mathrm{~nm}$ in both measurement periods. The inorganic species are predominately detected in the larger size fraction while organic show a much broader size distribution extending into size fractions below $100 \mathrm{~nm}$. Similar behavior of organic and inorganic species was found by Poulain et al. (2011) but with generally smaller mode diameters. Main differences between the two observation periods are the smaller modal diameter of nitrate and the larger fraction of organics that is observed at small sizes in 2009 compared to 2008. Maximum 


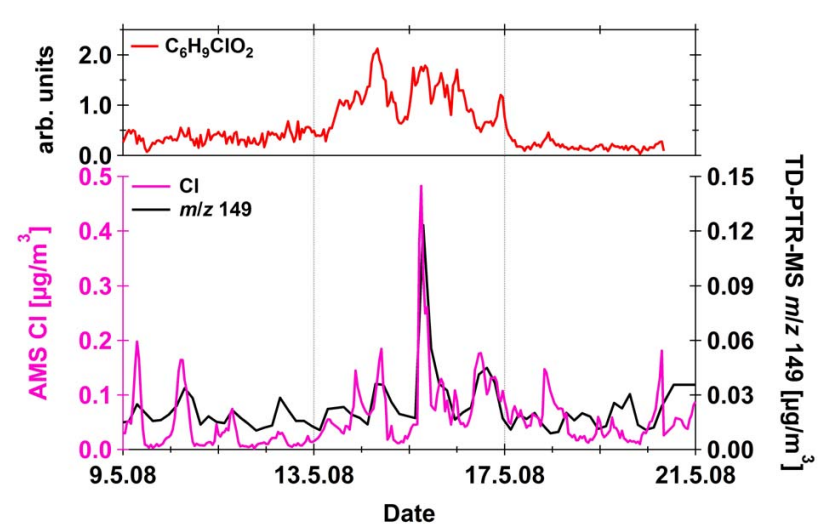

Fig. 7. Comparison of AMS to TD-PTR-MS results. Lower panel: AMS chloride (purple, left axis) and TD-PTR-MS mass trace at $m / z 149$ (black, right axis). Upper panel: AMS high resolution traces of $\mathrm{C}_{6} \mathrm{H}_{9} \mathrm{ClO}_{2}(\mathrm{~m} / \mathrm{z} 148.029$, red).

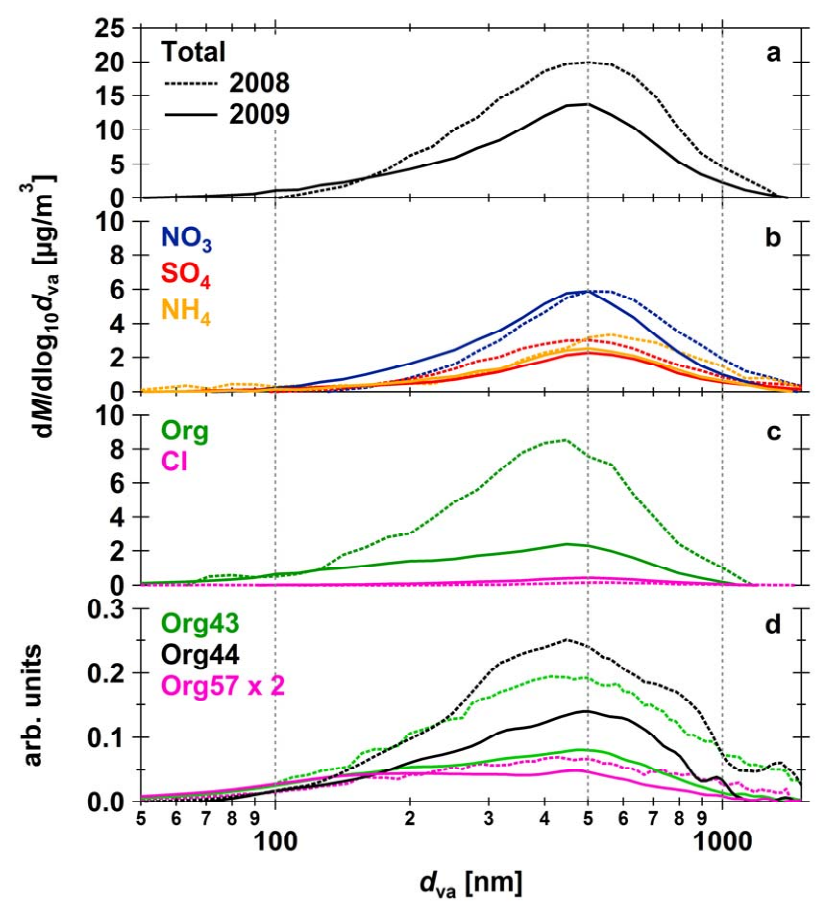

Fig. 8. Average size distribution for May 2008 (dashed lines) and March 2009 (solid lines) of the total mass (black, panel a), nitrate, sulfate, and ammonium (blue, red, and orange, respectively, panel b), organics, and chloride (green, and purple, respectively, panel c). Panel d shows the average size distributions of organic signal on $m / z 43, m / z 44$, and $m / z 57$ (Org43 (green), Org44 (black), and Org57 (purple), respectively). Note, that the signal of Org57 is multiplied by a factor of 2 for better display.

average mass fractions of nitrate were observed in the size range $500 \mathrm{~nm}-1000 \mathrm{~nm}$ in May 2008 and between $300 \mathrm{~nm}-$ $800 \mathrm{~nm}$ in March 2009. On average $30 \%$ of the observed organics are due to particles with diameters below $200 \mathrm{~nm}$ in
March 2009. In comparison only $20 \%$ of the organics are found in the size range below $200 \mathrm{~nm}$ in May 2008 Note that the mass fraction of organics in particles smaller than $200 \mathrm{~nm}$ was thus $\geq 60 \%$ in May 2008 and $\geq 35 \%$ in March 2009 .

Additionally, we present in panel d of Fig. 8 the average size distribution of the organic signal on $\mathrm{m} / \mathrm{z} 43$ (Org43, green), $m / z 44$ (Org44, black), and $m / z 55$ (Org57, purple). For better display, the signal of Org57 is multiplied by a factor of 2 . Org44 shows a clear maximum at about $450 \mathrm{~nm}$ to $500 \mathrm{~nm}$ Org 43 shows especially in 2009 a much broader size distribution. The size distribution of Org57 shows no distinct peak and extends far into the small size range of below $100 \mathrm{~nm}$. While Org43 and Org44 are generally associated with secondary organic aerosol, Org57 is associated with primary organic aerosol (Zhang et al., 2005b). An extended discussion on organic tracer analysis will follow in the upcoming section "Analysis of the organic phase".

\subsection{Diurnal cycles}

Figure 9 shows the diurnal averages of individual aerosol components for the episodes defined above based on main meteorological conditions. In 2008 (left part of Fig. 9) nitrate showed a night time maximum, if the entire measurement period is taken into account (upper most panel). While this maximum is very pronounced for the two episodes 1 May to 16 May (easterly winds, lowest left panel) and 21 May to 28 May (Sahara dust episode, second upper left panel) it is barely recognizable for the scavenged background situation (second lowest left panel). Night time maxima of nitrate not only in the fractional abundance but even in absolute mass concentration were found also at other measurement sites during the EUCAARI campaign (Poulain et al., 2011). Likely this is due to heterogeneous $\mathrm{N}_{2} \mathrm{O}_{5}$ conversion in the night and to volatilization of (ammonium) nitrate during the day. In contrast to nitrate, sulfate is characterized by a daytime maximum during all periods of the campaign, in accordance with its photochemical formation. Even a distinct peak in sulfate concentration right before noon can be recognized during the scavenged background situation. On average, organics show a slightly higher concentration during the night (upper most left panel). This night time maximum is most pronounced during the first half of May 2008 (lowest left panel). The average diurnal circle of the measurement campaign in March 2009 (upper most right panel) shows no pronounced maxima or minima in any specie. In the first measurement period from 24 February-3 March (lowest right panel) when southerly and westerly winds dominated, diurnal cycles with a night time maximum in nitrate, a daytime maximum in sulfate but only slight diurnal variations in organics and ammonium can be found. Though the second period in 2009 from 9 March to 17 March is a low loading period similar to the scavenged background situation on 2008 the diurnal evolution of the individual species is similar to the first period. This is most probably due to the same wind 
situation, where origins range from south to north but only passing westerly directions. As opposed to the two periods just mentioned, the wind originates from easterly directions in the third period from 17 March to 20 March. In this case, daytime maxima are observed not only in sulfate and ammonium but also in nitrate. In general, ammonium diurnal cycles in 2008 and 2009 can be explained based on the sum contribution of ammonium to ammonium nitrate and ammonium sulfate. The diurnal cycles of nitrate, sulfate and ammonium observed during the two campaigns agree well with observations reported by Schaap et al. (2011) for $\mathrm{PM}_{10}$ diurnal cycles measured with MARGA.

\subsection{Analysis of the organic phase}

\subsubsection{Organic tracer analysis}

Figure 10a and b show the time traces of different organic ions at mass to charge ratio $m / z 43, m / z 44, m / z 55$, and $m / z 57$ from top to bottom. Please note, in 2008 the signals of $\mathrm{C}_{2} \mathrm{H}_{3} \mathrm{O}^{+}$on $m / 243$ and $\mathrm{CO}_{2}^{+}$on $m / z 44$ are divided by a factor of 10 to allow for parallel display on the same axis as the other ions at the respective $\mathrm{m} / \mathrm{z}$. In 2009 this is only the case for $\mathrm{CO}_{2}^{+}$. Furthermore, the $\mathrm{CO}_{2}$ signal reported here represents the particulate $\mathrm{CO}_{2}^{+}$after correction for gas phase $\mathrm{CO}_{2}^{+}$interference. While the ions at $m / z 43$ and $m / z 44$ can be considered as tracers for oxidized organic aerosol (OOA) the signals at $\mathrm{m} / \mathrm{z} 55$ and $\mathrm{m} / \mathrm{z} 57$ are considered as tracers of aliphatic/hydrocarbon-like organic aerosol (HOA, Zhang et al., 2005a).

Due to the evaporation/ionization scheme of the AMS, almost all molecules are subject to substantial fragmentation. Therefore, the mass spectrum consists mainly of ions which are fragments of the mother ion. The high reproducibility of the fragmentation allows for assigning the ion fragments to specific molecular classes. That means for the ions presented here, that the non-oxidized ions most probably originate from aliphatic molecules or molecules which are dominated by an aliphatic structure. The ions containing a single oxygen atom most probably originate from molecules containing carbonyl groups such as aldehydes, ketones or ethers. Except for the $\mathrm{CO}_{2}^{+}$ion on $m / z 44$, which represents carboxyl compounds such as organic acids or esters, the concentration of ions containing two oxygen atom is highly dependent on the sample but generally and especially in these field campaigns negligible. Since the signals at $m / z 43$ and $m / z 44$ are generally dominated by the oxidized ions, they are associated with secondary organic aerosol (SOA). Opposite to this, $m / z 55$ and $m / 257$ are dominated by aliphatic ions and are therefore associated with primary organic aerosol (POA, Zhang et al., 2005b).

High-resolution analysis of the organic mass spectra allows for exact attribution of signal intensity to different ions at the same nominal mass. While the $\mathrm{CO}_{2}^{+}$ion is shown in black, the other oxygenated ions are shown in green and the

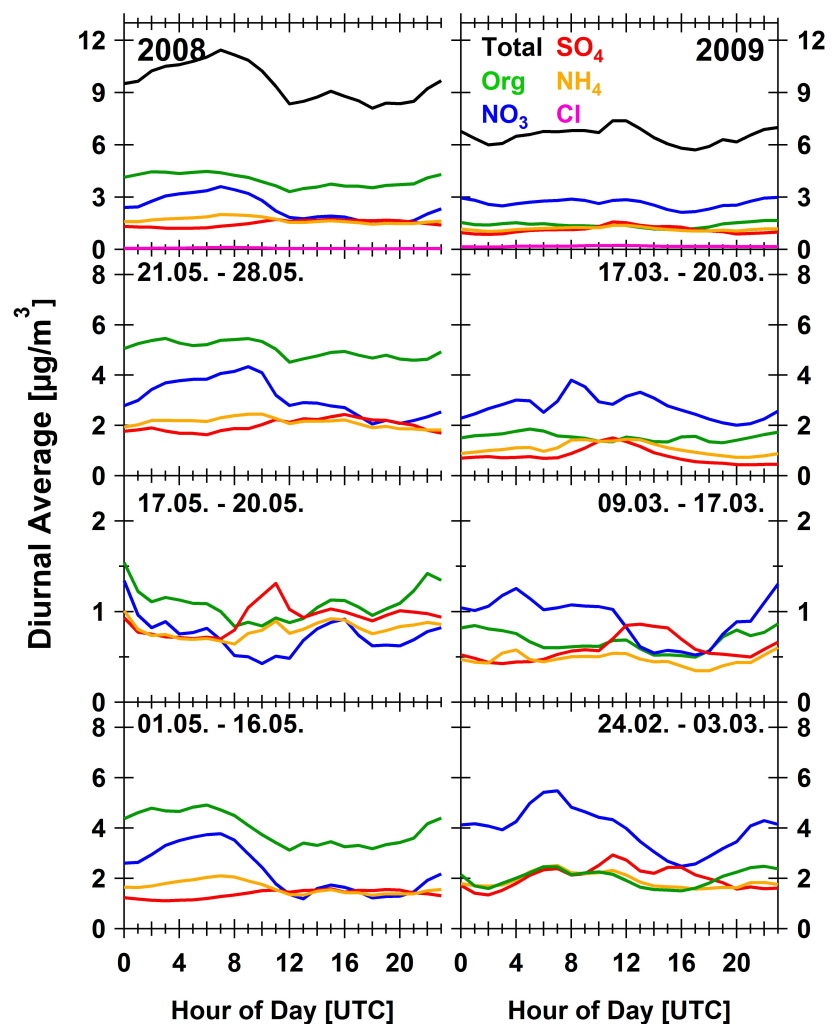

Fig. 9. Average diurnal variation of the total mass (black), organics (green), nitrate (blue), sulfate (red), ammonium (orange), and chloride (purple) as campaign averages (top panels) and for each of the individual meteorological periods encountered in May 2008 (left) and March 20009 (right).

aliphatic ions in gray. At the nominal mass of $m / z 43$ the ions $\mathrm{C}_{3} \mathrm{H}_{7}^{+}$and $\mathrm{C}_{2} \mathrm{H}_{3} \mathrm{O}^{+}$are detected. The latter is generally dominant and considered as a tracer of less oxidized/semivolatile organic aerosol (SV-OOA, $\mathrm{Ng}$ et al., 2010). $\mathrm{C}_{3} \mathrm{H}_{8}^{+}$ and $\mathrm{C}_{2} \mathrm{H}_{4} \mathrm{O}^{+}$as well as $\mathrm{CO}_{2}^{+}$contribute to the signal at $m / z 44 . \mathrm{CO}_{2}^{+}$is by far the dominating ion, originating from highly oxidized/low-volatile organic aerosol (LV-OOA) such as organic acids ( $\mathrm{Ng}$ et al., 2010). Except for a few instances, the time traces of all ions are highly correlated. An interesting phenomenon can be seen on the 15 May 2008. The aliphatic ions on $m / z 43, m / z 55$, and $m / z 57$ show a distinct peak in the early hours which is simultaneous with a very distinct peak in the chloride time trace. This supports the assumption of an organic origin of that chloride. This chloride peak was not only detected by the AMS but also by the collocated instruments MARGA-Sizer (Fig. 5) and TD-PRTMS (Fig. 7) The temporal correlation of the AMS chloride peak with the TD-PTR-MS $m / z 149$ and the aliphatic ion time traces further supports the organic origin of AMS detected chloride.

As already seen in other field campaigns (Zhang et al., 2005a; Alfarra et al., 2004) and can be seen in the pie chart 

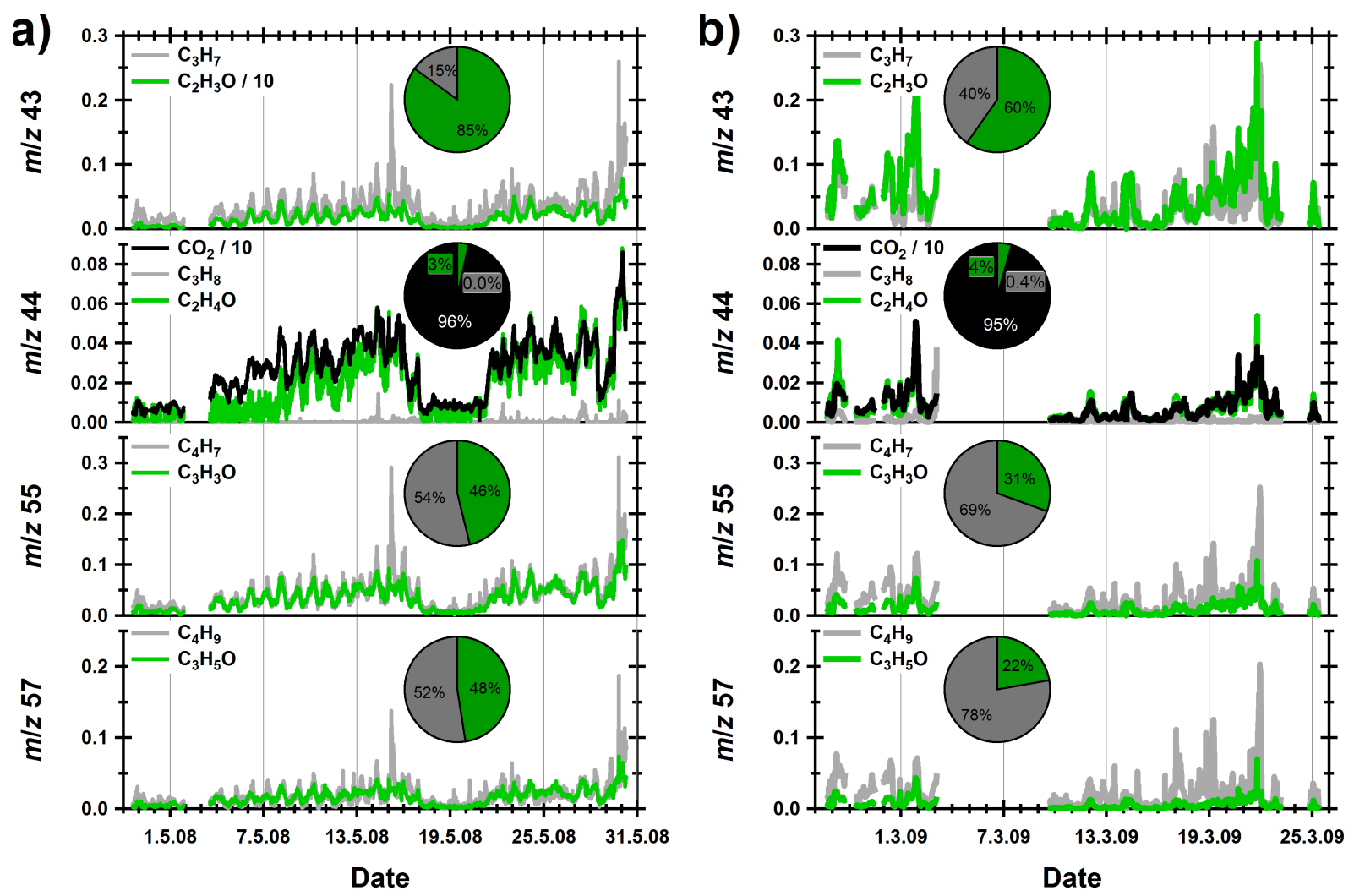

Fig. 10. Time traces of different organic ions at mass to charge ratio $\mathrm{m} / \mathrm{z} 43, \mathrm{~m} / \mathrm{z} 44, \mathrm{~m} / \mathrm{z} 55$, and $\mathrm{m} / \mathrm{z} 57$ from top to bottom in May 2008 (a) and March 2009 (b), respectively. Please note, in 2008 the signals of $\mathrm{C}_{2} \mathrm{H}_{3} \mathrm{O}^{+}$on $\mathrm{m} / z 43$ and $\mathrm{CO}_{2}^{+}$on $\mathrm{m} / z 44$ are divided by a factor of 10 to allow for parallel display on the same axis as the other ions at the respective $m / z$. In 2009 this is only the case for $\mathrm{CO}_{2}^{+}$.

insets, $m / z 43$ and $m / z 44$ are dominated by the oxidized component and $\mathrm{m} / \mathrm{z} 55$, and $\mathrm{m} / z 57$ are dominated by the aliphatic components. The pie charts give the contribution of the different ions a the respective $\mathrm{m} / \mathrm{z}$. The contribution of oxidized to aliphatic ions differs significantly for the two measurement periods. In general, the fraction of oxidized ions is higher in May 2008. We interpret this as a result of the increases oxidative potential of the atmosphere in spring/summer compared to winter. Higher intensity accompanied by longer duration of sunlight increases the production of $\mathrm{OH}$ radicals, which are the major oxidants in the atmosphere (FinlaysonPitts and Pitts, 2000) during day time. E.g. while $\mathrm{C}_{2} \mathrm{H}_{3} \mathrm{O}^{+}$ contributes $85 \%$ of the signal at $m / z, 43$ in May 2008, the contribution is lowered to only $60 \%$ in March 2009. Similar behavior can be observed on $\mathrm{m} / \mathrm{z}, 55$ and $\mathrm{m} / \mathrm{z}, 57$ where the signal is composed of contributions by $\mathrm{C}_{4} \mathrm{H}_{7}^{+}$and $\mathrm{C}_{3} \mathrm{H}_{3} \mathrm{O}^{+}$, and $\mathrm{C}_{4} \mathrm{H}_{9}^{+}$and $\mathrm{C}_{3} \mathrm{H}_{5} \mathrm{O}^{+}$, respectively. As already stated, these mass to charge ratios are generally dominated by the nonoxidized ions and associated with fresh, primary and/or anthropogenic emissions (Zhang et al., 2005a). The dominance of the aliphatic ion increases from summer to winter. The contribution of $\mathrm{C}_{4} \mathrm{H}_{7}^{+}$on $\mathrm{m} / \mathrm{z} 55$ increases from slightly over half to more than two thirds. This increase is even more pronounced for $\mathrm{C}_{4} \mathrm{H}_{9}^{+}$on $m / z 57$, where the contribution in- creases from slightly over half to more than three quarters. The overall increase in the contribution of aliphatic ions is rather due to the significant decrease of the oxygenated ions than the moderate increase of the aliphatic ions from summer to winter.

\subsubsection{Diurnal cycles of O:C and $\mathrm{H}: \mathrm{C}$ ratios}

Further insight to the composition of the organic particulate phase can be gained by investigating the oxygen to carbon $(\mathrm{O}: \mathrm{C})$ and hydrogen to carbon ratio $(\mathrm{H}: \mathrm{C})$, respectively. The $\mathrm{O}: \mathrm{C}$ and $\mathrm{H}: \mathrm{C}$ ratios can be determined from high resolution analysis of the organic mass spectra (Aiken et al., 2007). Figure 11a and $\mathrm{b}$ show the diurnal cycles of the $\mathrm{O}: \mathrm{C}$ ratio (green dots, left axes) and $\mathrm{H}: \mathrm{C}$ ratios (gray triangles, right axes) in May 2008 and March 2009, respectively. The top panel in each graph shows the diurnal average for the entire measurement period and the three panels below show the average diurnal cycles for three specific time intervals. The O:C and $\mathrm{H}: \mathrm{C}$ ratios are highly anti-correlated in both measurement periods. The average O:C ratio in May 2008 is significantly higher than in March 2009. While the ratio reaches values of almost 0.7 in May 2008, which corresponds to highly oxidized LV-OOA (Aiken et al., 2008), the O:C ratio did not 
a)

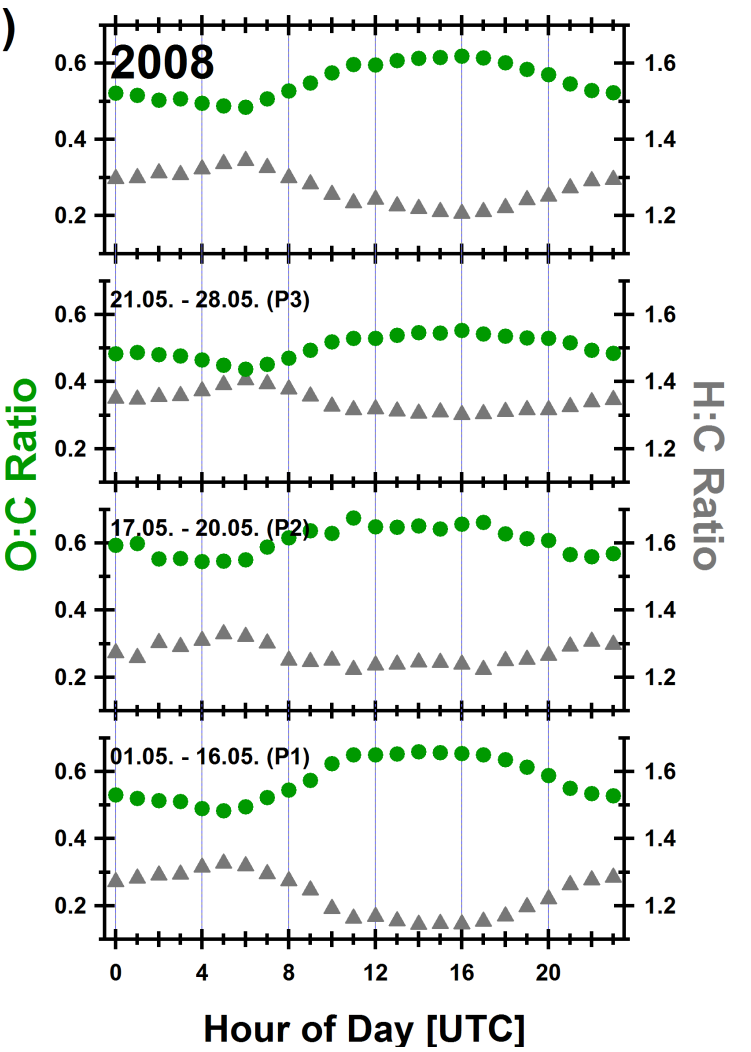

b)

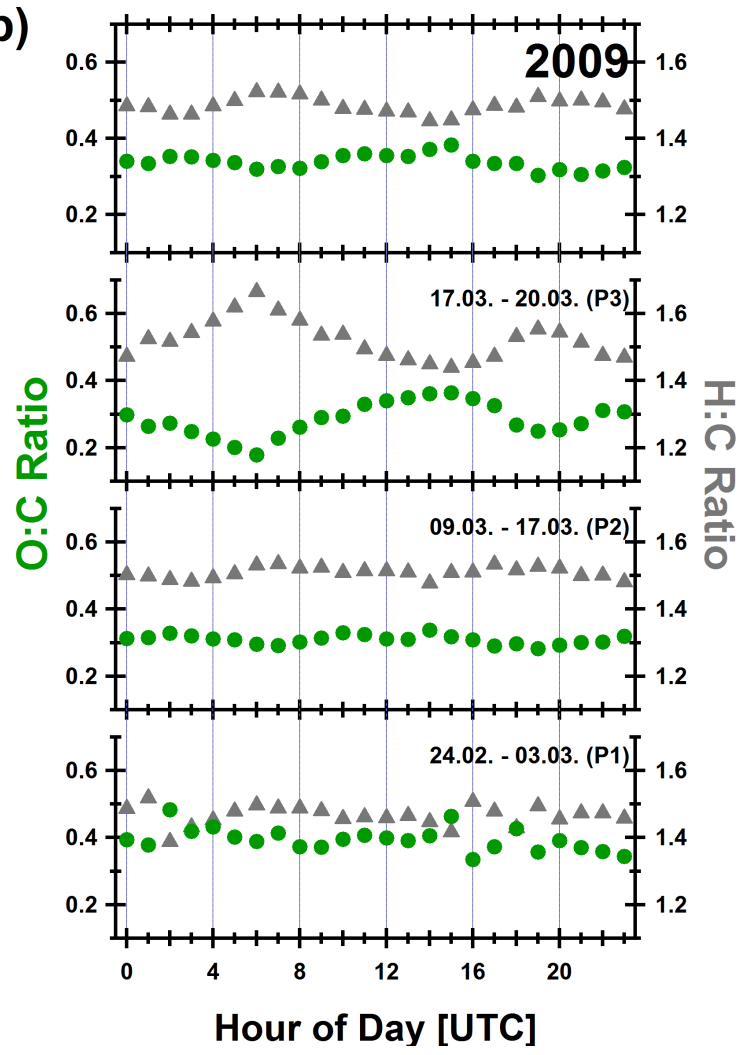

Fig. 11. Diurnal cycles of the O:C ratio (green dots, left axes) and H:C ratios (gray triangles, right axes) in May 2008 (a) and March 2009 (b), respectively. The top panel in each graph shows the diurnal average for the entire measurement period and the three panels below show the average diurnal cycle for three specific time intervals.

exceed 0.4 in winter 2009. These low values are generally associated with less oxidized SV-OOA (Jimenez et al., 2009).

On a daily basis, the O:C ratios show a minimum in the early morning hours and a maximum during the daytime. This maximum is pronounced and extended in May 2008 compared to March 2009 which correlates with more hours of sunshine in May and therefore longer time of photochemical aging. This indicates local aging of organic compounds by photochemical oxidation during the daytime. Interestingly, the period $\mathrm{P} 2$ during scavenged background conditions in May 2008 shows a reduced amplitude in O:C ratio accompanied by a high average value of 0.61 . The combination of these two facts indicates the detected aerosol particles were aged and subject to long range transport in addition to the absence of local sources for OOA (Hildebrandt et al., 2010). In both measurement periods, the $\mathrm{H}: \mathrm{C}$ ratios show a maximum in the morning hours. In May 2008 a moderate increase between 04:00 $\mathrm{h}$ and 08:00 $\mathrm{h}$ can be seen. The ratio peaks between 05:00 $\mathrm{h}$ and 06:00 $\mathrm{h} \mathrm{UTC}$, which corresponds to $2 \mathrm{~h}$ later in the day in local time. Therefore, the peak on $\mathrm{H}: \mathrm{C}$ ratio appears at the time of morning traffic, which is generally accompanied by an increased emission of compounds high in $\mathrm{H}: \mathrm{C}$ and low in O:C ratios from fossil fuel emissions (Aiken et al., 2008). In March 2009, morning peak values in H:C are found between $06: 00 \mathrm{~h}$ and 07:00 $\mathrm{h}$ UTC which also corresponds to a local time of $07: 00 \mathrm{~h}$ to $08: 00 \mathrm{~h}$ due to reduced time shift of only one hour in winter. The decrease in $\mathrm{H}: \mathrm{C}$ ratio during the daytime is not only due to the transformation from aliphatic to oxygenated compounds but also due to temperature increase. Aliphatic compounds high in $\mathrm{H}: \mathrm{C}$ tend to have higher vapor pressures than oxygenated species, causing the aliphatic compounds to evaporate from the particulate phase with increasing temperature. The temperature dependence of $\mathrm{O}: \mathrm{C}$ and $\mathrm{H}: \mathrm{C}$ ratios was shown by Huffman et al. (2009) by thermodenuder experiments on ambient aerosol particles. Reduced photochemical ageing due to reduced sunlight in addition to lower ambient temperatures can explain the significantly higher H:C ratios in March 2009. As expected, elevated $\mathrm{H}: \mathrm{C}$ ratios were measured in winter compared to summer. While in March 2009, the H:C ratio fluctuates around 1.5, it fluctuates around 1.3 in May 2008. The increased $\mathrm{H}: \mathrm{C}$ ratio corresponds to the finding of the tracer analysis showing reduced aging of the aerosol particles due to a lowered oxidative potential of the atmosphere in winter time. 


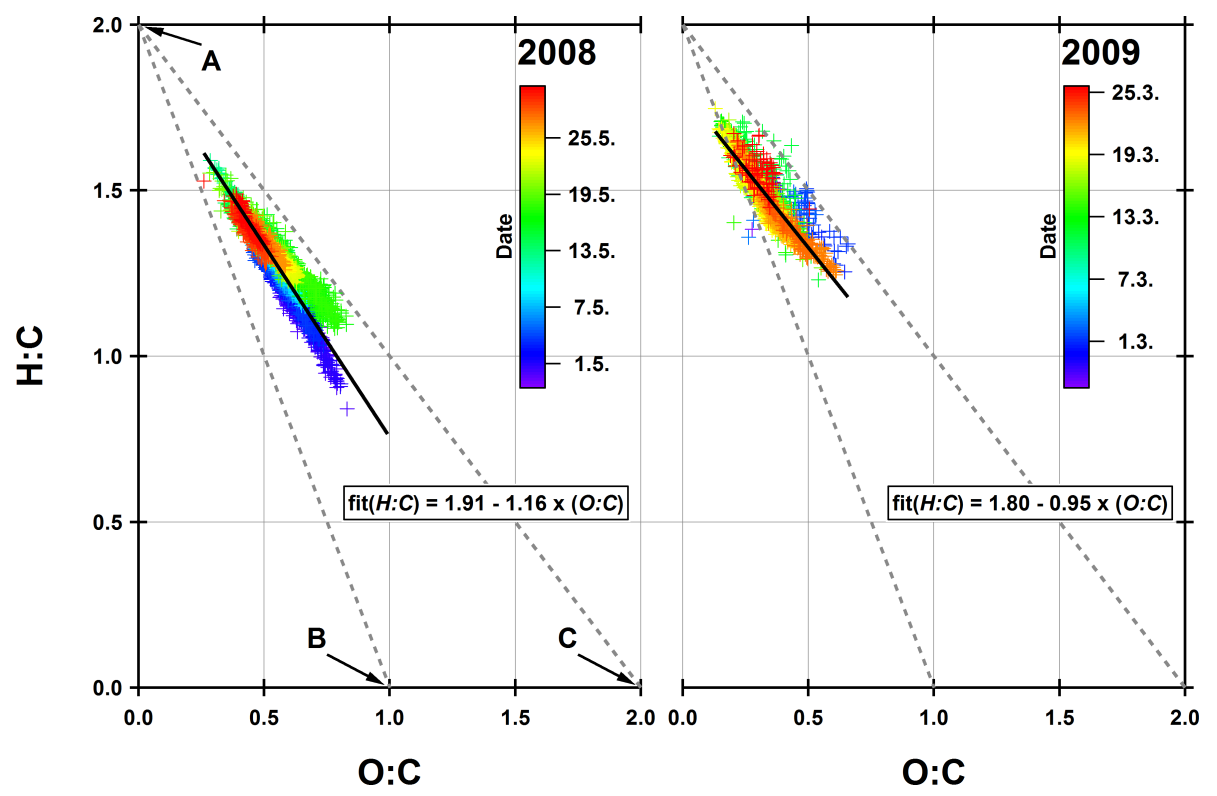

Fig. 12. van Krevelen diagram presenting the H:C and O:C ratios for the two campaigns in May 2008 (left) and March 2008 (right), respectively. The data is colored by time and the result of a linear regression (black solid line) is shown. Transformation from $\mathrm{CH}_{2}$ to $\mathrm{CO}$ and $\mathrm{CO}_{2}$ is indicated by the left ( $\mathbf{A}$ to $\left.\mathbf{B}\right)$ and right ( $\mathbf{A}$ to $\mathbf{C}$ ) dashed grey line, respectively.

\subsubsection{O:C and $\mathrm{H}: \mathrm{C}$ in the van Krevelen diagram}

The $\mathrm{H}: \mathrm{C}$ and $\mathrm{O}: \mathrm{C}$ ratios of an ensemble of measurements can be graphically illustrated in a van Krevelen diagram (van Krevelen, 1950, Fig. 12). Here, the H:C ratio is plotted versus the $\mathrm{O}: \mathrm{C}$ ratio. Three distinct points in the graph are labeled in the left part of Fig. 12 with the letters A, B, and C, respectively. Label A is at a $\mathrm{H}: \mathrm{C}$ ratio of 2.0 and an $\mathrm{O}: \mathrm{C}$ ratio of 0.0. This corresponds to a theoretical hydrocarbon consisting solely of (- $\left.\mathrm{CH}_{2}-\right)$-segments. The $\mathrm{H}: \mathrm{C}$ ratio of 0.0 at an O:C ratio of 1.0 labeled $\mathrm{B}$ corresponds to a theoretical hydrocarbon consisting solely of $(-\mathrm{C}(=\mathrm{O})-)$-segments. And the $\mathrm{H}: \mathrm{C}$ ratio of 0.0 at an $\mathrm{O}: \mathrm{C}$ ratio of 2.0 corresponds to a theoretical hydrocarbon consisting solely of $(-\mathrm{C}(=\mathrm{O}) \mathrm{O}-)$-segments is labeled $\mathrm{C}$. The transition from point $\mathrm{A}$ to $\mathrm{B}$ corresponds to the transformation of a $\left(-\mathrm{CH}_{2}-\right)$-segment into a $(-\mathrm{C}(=\mathrm{O})-$-)segment, i.e. a carbonyl group, is highlighted by the left grey dashed line with a slope of -2 . The transition from point $A$ to point $\mathrm{C}$ corresponds to the transformation of a $\left(-\mathrm{CH}_{2}-\right)$ segment into a $(-\mathrm{C}(=\mathrm{O}) \mathrm{O}-)$-segment, i.e. a carboxyl group, is highlighted by the right grey dashed line with a slope of -1 . It is generally assumed that the final stage of atmospheric oxidation is reached, when all organic carbon is transformed to $\mathrm{CO}_{2}$.

As can be seen in Fig. 12, the data acquired during the two field campaigns in Cabauw in May 2008 and March 2009, respectively lies within the two grey dashed lines. The data of the campaign in May 2008 colored by time is presented in the left part of Fig. 12. The data points are lumped between $\mathrm{O}: \mathrm{C}=0.25 / \mathrm{H}: \mathrm{C}=1.61$ and $\mathrm{O}: \mathrm{C}=0.79 / \mathrm{H}: \mathrm{C}=0.91$. A linear regression to these data points yields a slope of -1.16 and an offset of $1.91\left(R^{2}=0.85\right)$. The linear regression to the data points of the campaign in March 2009 presented in the right part of Fig. 12 yields a slope of -0.95 and an offset of $1.80\left(R^{2}=0.80\right)$ and is focused to the region between $\mathrm{O}: \mathrm{C}=0.16 / \mathrm{H}: \mathrm{C}=1.70$ and $\mathrm{O}: \mathrm{C}=0.64 / \mathrm{H}: \mathrm{C}=1.26$. As could already be anticipated from the diurnal cycles of these two ratios in Fig. 11, the data points of 2008 ratios span over a broader range and are shifted to generally lower $\mathrm{H}: \mathrm{C}$ and higher O:C ratios compared to 2009. Though the slopes are slightly different, they are close to a value of -1 in both years. As described above, this slope is associated with the transformation of a $\left(-\mathrm{CH}_{2}-\right)$-segment into a carboxylicsegment. This can be achieved also by the transformation of two $\left(-\mathrm{CH}_{2}-\right)$-segments into a hydroxycarbonyl-group $(-\mathrm{C}(=\mathrm{O})-\mathrm{HCOH}-)$.

Though the organic aerosol measured at Cabauw during the two campaigns consisted of a multitude of different compounds, the data points are focused into a fairly narrow range within the van Krevelen diagram. This result was also found by Heald et al. (2010), who investigated a large number of different ambient and laboratory measurements, predominantly showing a slope of -1 in the van Krevelen diagram. We agree to their conclusion that the differences in compound composition and aging processes for individual campaigns is rather reflected in the spread of the data points than by a significantly different location within the diagram or significantly different regression slopes. Even detailed analysis of the van Krevelen diagram on a diurnal basis did not reveal any evidence of hydration/dehydration reactions which would cause a slope of +1 . Therefore, we conclude if at all 
oligomerization reactions play only a minimal role during the two campaigns.

\section{Summary and conclusion}

Extensive aerosol chemical composition measurements over the course of several weeks were performed at the CESAR tower, The Netherlands, in May 2008 and March 2009. While the measurement period in 2008 was dominated by organics $(40 \%)$, nitrate was the dominant specie detected in 2009 $(42 \%)$. In both years, nitrate was the most abundant inorganic specie detected in AMS and MARGA measurements. The phenomenon of high nitrate fractional abundances is not only typical for the measurement location (ten Brink et al., 2009) but is known to occur all over Europe (ten Brink et al., 1997; Putaud et al., 2004). For the first time, a solely nitrate dependent $\mathrm{CE}$ was applied for quantifying ambient AMS data. This allows for an easy and straight forward correction of the $\mathrm{CE}$. The $\mathrm{CE}$ increased linearly for particulate nitrate fractions exceeding 0.3 . A possible explanation is the reduced tendency of particles bouncing at elevated nitrate content. This parameterization seems to be valid for all central European measurement locations during the EUCAARI measurement campaign (Nemitz et al., 2012). The average aerosol particulate mass loading was $10.21 \mu \mathrm{g} \mathrm{m}^{-3}$ in 2008 and $6.85 \mu \mathrm{g} \mathrm{m}^{-3}$ in 2009, which is in good agreement with $\mathrm{PM}_{2.5}$ concentrations determined at different rural European locations (Van Dingenen et al., 2004).

Size resolved mass distribution measurements of the individual species detected in the AMS indicate a mode diameter at $400 \mathrm{~nm}$ to $500 \mathrm{~nm}$ for the total mass as well as for the inorganic species. The mass distribution of organics is much broader and extents into the size range below $100 \mathrm{~nm}$. Similar size distributions with inorganic species dominating in the larger size fraction and a bimodal behavior of organics have often been observed in AMS measurements independent of location (Alfarra et al., 2004; Allan et al., 2003).

Comparison of AMS total mass to the mass derived from SMPS measurements show high qualitative and quantitative agreement. In 2008 a MARGA-Sizer was operated at CESAR tower and comparison of the various inlet channels to AMS data show best correlation for the $1 \mu \mathrm{m}$ channel. However, the mass concentrations of this channel were on average a factor of 1.6 higher than the AMS total mass loading. Best quantitative agreement between AMS and MARGASizer was obtained through the $\mathrm{PM}_{0.56}$ channel. Since this data present the first comparison of AMS and MARGA-Sizer of ambient aerosol particles, further parallel sampling campaigns are needed to investigate the presented discrepancy. For the first time, a comparison of AMS data to data obtained with the newly developed TD-PTR-MS is performed. Surprisingly, best qualitative and quantitative agreement was achieved for the particulate nitrate concentration, which is dominantly of inorganic origin. The total organic mass de- tected by the TD-PTR-MS accounted for $30 \%$ to $85 \%$ of the organic mass detected by the AMS depending on the measurement period. Further intensive parallel measurements are needed in the future for a deeper understanding of differences in detected mass and temporal evolution.

High resolution analysis was performed to gain insight into the composition of the organic particulate phase. The examination of specific organic tracers on $m / z 43, m / z 44$, $m / z 55$, and $m / z, 57$ shows an increased contribution of oxygenated compounds in May 2008 compared to March 2009. This is further supported by the investigation of the diurnal $\mathrm{O}: \mathrm{C}$ and $\mathrm{H}: \mathrm{C}$ ratios in both years. While the $\mathrm{O}: \mathrm{C}$ ratio reaches values of almost 0.7 associated with $\mathrm{LV}-\mathrm{OOA}$ (Aiken et al., 2008) in May 2008, the O:C ratio does not exceed 0.4 , which is associated with SV-OOA. The reduced aging of the organic particulate matter in combination with an increased H:C ratio in winter/spring 2009 can be explained by reduced photochemical activity and increased condensation of aliphatic compounds due to the low average temperature.

Acknowledgements. This work was supported through the FP6 project EUCAARI (Contract 34684) and EUSAAR (European Supersites for Atmospheric Aerosol Research, EU FP6 Integrated Infrastructures Initiatives project, No. FP6-026140)

We appreciate the support from KNMI in hosting the experiment at Cabauw and for the access to meteorological data from the tower. The authors thank the CESAR tower team, especially Marcel Brinkenberg and Jaques Warmer for the big support during both campaigns. Further thanks go to P. Jongejan for his effort in operating both MARGA's and Marcel Moerman for performing the size distribution measurements.

Edited by: V.-M. Kerminen

\section{References}

Aiken, A. C., DeCarlo, P. F., and Jimenez, J. L.: Elemental Analysis of Organic Species with Electron Ionization HighResolution Mass Spectrometry, Anal. Chem., 79, 8350-8358, doi:10.1021/ac071150w, 2007.

Aiken, A. C., DeCarlo, P. F., Kroll, J. H., Worsnop, D. R., Huffman, J. A., Docherty, K. S., Ulbrich, I. M., Mohr, C., Kimmel, J. R., Sueper, D., Sun, Y., Zhang, Q., Trimborn, A., Northway, M., Ziemann, P. J., Canagaratna, M. R., Onasch, T. B., Alfarra, M. R., Prevot, A. S. H., Dommen, J., Duplissy, J., Metzger, A., Baltensperger, U., and Jimenez, J. L.: O/C and OM/OC Ratios of Primary, Secondary, and Ambient Organic Aerosols with HighResolution Time-of-Flight Aerosol Mass Spectrometry, Environ. Sci. Techol., 42, 4478-4485, doi:10.1021/es703009q, 2008.

Aiken, A. C., Salcedo, D., Cubison, M. J., Huffman, J. A., DeCarlo, P. F., Ulbrich, I. M., Docherty, K. S., Sueper, D., Kimmel, J. R., Worsnop, D. R., Trimborn, A., Northway, M., Stone, E. A., Schauer, J. J., Volkamer, R. M., Fortner, E., de Foy, B., Wang, J., Laskin, A., Shutthanandan, V., Zheng, J., Zhang, R., Gaffney, J., Marley, N. A., Paredes-Miranda, G., Arnott, W. P., Molina, 
L. T., Sosa, G., and Jimenez, J. L.: Mexico City aerosol analysis during MILAGRO using high resolution aerosol mass spectrometry at the urban supersite (T0) - Part 1: Fine particle composition and organic source apportionment, Atmos. Chem. Phys., 9, 6633-6653, doi:10.5194/acp-9-6633-2009, 2009.

Alfarra, M. R., Coe, H., Allan, J. D., Bower, K. N., Boudries, H., Canagaratna, M. R., Jimenez, J. L., Jayne, J. T., Garforth, A. A., Li, S.-M., and Worsnop, D. R.: Characterization of urban and rural organic particulate in the Lower Fraser Valley using two Aerodyne Aerosol Mass Spectrometers, Atmos. Environ., 38, 5745-5758, doi:10.1016/j.atmosenv.2004.01.054, 2004.

Allan, J. D., Bower, K. N., Coe, H., Boudries, H., Jayne, J. T., Canagaratna, M. R., Millet, D. B., Goldstein, A. H., Quinn, P. K., Weber, R. J., and Worsnop, D. R.: Submicron aerosol composition at Trinidad Head, California, during ITCT 2K2: Its relationship with gas phase volatile organic carbon and assessment of instrument performance, J. Geophys. Res.-Atmos., 109, D23S24, doi:10.1029/2003jd004208, 2004.

Canagaratna, M. R., Jayne, J. T., J.L., J., J.D., A., M.R., A., Zhang, Q., Onasch, T. B., Drewnick, F., Coe, H., Middlebrook, A., Delia, A., Williams, L. R., Trimborn, A. M., Northway, M. J., DeCarlo, P. F., Kolb, C. E., Davidovits, P., and Worsnop, D. R.: Chemical and microphysical characterization of ambient aerosols with the aerodyne aerosol mass spectrometer, Mass Spectrom. Rev., 26, 185-222, doi:10.1002/mas.20115, 2007.

Crosier, J., Allan, J. D., Coe, H., Bower, K. N., Formenti, P., and Williams, P. I.: Chemical composition of summertime aerosol in the Po Valley (Italy), northern Adriatic and Black Sea, Q. J. Roy. Meteorol. Soc., 133, 61-75, doi:10.1002/qj.88, 2007.

DeCarlo, P. F., Kimmel, J. R., Trimborn, A., Northway, M. J., Jayne, J. T., Aiken, A. C., Gonin, M., Fuhrer, K., Horvath, T., Docherty, K. S., Worsnop, D. R., and Jimenez, J. L.: Field-Deployable, High-Resolution, Time-of-Flight Aerosol Mass Spectrometer, Anal. Chem., 78, 8281-8289, doi:10.1021/ac061249n, 2006.

Dentener, F. J. and Crutzen, P. J.: Reaction of $\mathrm{N}_{2} \mathrm{O}_{5}$ on Tropospheric Aerosols: Impact on the Global Distributions of $\mathrm{NO}_{\mathrm{x}}, \mathrm{O}_{3}$, and $\mathrm{OH}$, J. Geophys. Res., 98, 7149-7163, doi:10.1029/92jd02979, 1993.

Drewnick, F., Schwab, J. J., Jayne, J. T., Canagaratna, M., Worsnop, D. R., and Demerjian, K. L.: Measurement of Ambient Aerosol Composition During the PMTACS-NY 2001 Using an Aerosol Mass Spectrometer. Part I: Mass Concentrations, Aerosol Sci. Tech., 38, 92-103, doi:10.1080/02786820390229507, 2004.

Finlayson-Pitts, B. J. and Pitts, J. N.: Chemistry of the Upper and Lower Troposphere, Academic Press, San Diego, USA, 2000.

Hallquist, M., Wenger, J. C., Baltensperger, U., Rudich, Y., Simpson, D., Claeys, M., Dommen, J., Donahue, N. M., George, C., Goldstein, A. H., Hamilton, J. F., Herrmann, H., Hoffmann, T., Iinuma, Y., Jang, M., Jenkin, M. E., Jimenez, J. L., KiendlerScharr, A., Maenhaut, W., McFiggans, G., Mentel, T. F., Monod, A., Prévôt, A. S. H., Seinfeld, J. H., Surratt, J. D., Szmigielski, R., and Wildt, J.: The formation, properties and impact of secondary organic aerosol: current and emerging issues, Atmos. Chem. Phys., 9, 5155-5235, doi:10.5194/acp-9-5155-2009, 2009.

Hamburger, T., McMeeking, G., Minikin, A., Birmili, W., Dall'Osto, M., O’Dowd, C., Flentje, H., Henzing, B., Junninen, H., Kristensson, A., de Leeuw, G., Stohl, A., Burkhart, J. F., Coe, H., Krejci, R., and Petzold, A.: Overview of the synop- tic and pollution situation over Europe during the EUCAARILONGREX field campaign, Atmos. Chem. Phys., 11, 10651082, doi:10.5194/acp-11-1065-2011, 2011.

Hansel, A., Jordan, A., Holzinger, R., Prazeller, P., Vogel, W., and Lindinger, W.: Proton-Transfer Reaction Mass-Spectrometry: On-line Trace Gas Analysis at the ppb Level, Int. J. Mass Spectrom., 150, 609-619, doi:10.1016/0168-1176(95)04294-u, 1995.

Heald, C. L., Kroll, J. H., Jimenez, J. L., Docherty, K. S., DeCarlo, P. F., Aiken, A. C., Chen, Q., Martin, S. T., Farmer, D. K., and Artaxo, P.: A simplified description of the evolution of organic aerosol composition in the atmosphere, Geophys. Res. Lett., 37, L08803, doi:10.1029/2010g1042737, 2010.

Hildebrandt, L., Engelhart, G. J., Mohr, C., Kostenidou, E., Lanz, V. A., Bougiatioti, A., DeCarlo, P. F., Prevot, A. S. H., Baltensperger, U., Mihalopoulos, N., Donahue, N. M., and Pandis, S. N.: Aged organic aerosol in the Eastern Mediterranean: the Finokalia Aerosol Measurement Experiment - 2008, Atmos. Chem. Phys., 10, 4167-4186, doi:10.5194/acp-10-4167-2010, 2010.

Holzinger, R., Kasper-Giebl, A., Staudinger, M., Schauer, G., and Röckmann, T.: Analysis of the chemical composition of organic aerosol at the Mt. Sonnblick observatory using a novel high mass resolution thermal-desorption proton-transfer-reaction mass-spectrometer (HR-TD-PTR-MS), Atmos. Chem. Phys., 10, 10111-10128, doi:10.5194/acp-10-10111-2010, 2010 a.

Holzinger, R., Williams, J., Herrmann, F., Lelieveld, J., Donahue, N. M., and Röckmann, T.: Aerosol analysis using a ThermalDesorption Proton-Transfer-Reaction Mass Spectrometer (TDPTR-MS): a new approach to study processing of organic aerosols, Atmos. Chem. Phys., 10, 2257-2267, doi:10.5194/acp10-2257-2010, 2010b.

Huffman, J. A., Jayne, J. T., Drewnick, F., Aiken, A. C., Onasch, T., Worsnop, D. R., and Jimenez, J. L.: Design, Modeling, Optimization, and Experimental Tests of a Particle Beam Width Probe for the Aerodyne Aerosol Mass Spectrometer, Aerosol Sci. Tech., 39, 1143-1163, doi:10.1080/02786820500423782, 2005.

Huffman, J. A., Docherty, K. S., Aiken, A. C., Cubison, M. J., Ulbrich, I. M., DeCarlo, P. F., Sueper, D., Jayne, J. T., Worsnop, D. R., Ziemann, P. J., and Jimenez, J. L.: Chemically-resolved aerosol volatility measurements from two megacity field studies, Atmos. Chem. Phys., 9, 7161-7182, doi:10.5194/acpd-9-26452009, 2009.

IPCC: Intergovernmental Panel on Climate Change: Climate Change 2007: The Physical Science Basis, Cambrige University Press, 2007.

Jayne, J. T., Leard, D. C., Zhang, X. F., Davidovits, P., Smith, K. A., Kolb, C. E., and Worsnop, D. R.: Development of an aerosol mass spectrometer for size and composition analysis of submicron particles, Aerosol Sci. Tech., 33, 49-70, doi:10.1080/027868200410840, 2000.

Jimenez, J. L., Jayne, J. T., Shi, Q., Kolb, C. E., Worsnop, D. R., Yourshaw, I., Seinfeld, J. H., Flagan, R. C., Zhang, X. F., Smith, K. A., Morris, J. W., and Davidovits, P.: Ambient aerosol sampling using the Aerodyne Aerosol Mass Spectrometer, J. Geophys. Res.-Atmos., 108, 8425, doi:10.1029/2001JD001213, 2003.

Jimenez, J. L., Canagaratna, M. R., Donahue, N. M., Prevot, A. S. H., Zhang, Q., Kroll, J. H., DeCarlo, P. F., Allan, J. D., Coe, H., Ng, N. L., Aiken, A. C., Docherty, K. S., Ulbrich, I. M., 
Grieshop, A. P., Robinson, A. L., Duplissy, J., Smith, J. D., Wilson, K. R., Lanz, V. A., Hueglin, C., Sun, Y. L., Tian, J., Laaksonen, A., Raatikainen, T., Rautiainen, J., Vaattovaara, P., Ehn, M., Kulmala, M., Tomlinson, J. M., Collins, D. R., Cubison, M. J., E, Dunlea, J., Huffman, J. A., Onasch, T. B., Alfarra, M. R., Williams, P. I., Bower, K., Kondo, Y., Schneider, J., Drewnick, F., Borrmann, S., Weimer, S., Demerjian, K., Salcedo, D., Cottrell, L., Griffin, R., Takami, A., Miyoshi, T., Hatakeyama, S., Shimono, A., Sun, J. Y., Zhang, Y. M., Dzepina, K., Kimmel, J. R., Sueper, D., Jayne, J. T., Herndon, S. C., Trimborn, A. M., Williams, L. R., Wood, E. C., Middlebrook, A. M., Kolb, C. E., Baltensperger, U., and Worsnop, D. R.: Evolution of Organic Aerosols in the Atmosphere, Science, 326, 1525-1529, doi:10.1126/science.1180353, 2009.

Kleinman, L. I., Springston, S. R., Daum, P. H., Lee, Y. N., Nunnermacker, L. J., Senum, G. I., Wang, J., Weinstein-Lloyd, J., Alexander, M. L., Hubbe, J., Ortega, J., Canagaratna, M. R., and Jayne, J.: The time evolution of aerosol composition over the Mexico City plateau, Atmos. Chem. Phys., 8, 1559-1575, doi:10.5194/acp-8-1559-2008, 2008.

Kulmala, M., Asmi, A., Lappalainen, H. K., Carslaw, K. S., Pöschl, U., Baltensperger, U., Hov, Ø., Brenquier, J. L., Pandis, S. N., Facchini, M. C., Hansson, H. C., Wiedensohler, A., and O'Dowd, C. D.: Introduction: European Integrated Project on Aerosol Cloud Climate and Air Quality interactions (EUCAARI) - integrating aerosol research from nano to global scales, Atmos. Chem. Phys., 9, 2825-2841, doi:10.5194/acp-9-2825-2009, 2009.

Kulmala, M., Asmi, A., Lappalainen, H. K., Baltensperger, U., Brenguier, J.-L., Facchini, M. C., Hansson, H.-C., Hov, Ø., O’Dowd, C. D., Pöschl, U., Wiedensohler, A., Boers, R., Boucher, O., de Leeuw, G., Denier van der Gon, H. A. C., Feichter, J., Krejci, R., Laj, P., Lihavainen, H., Lohmann, U., McFiggans, G., Mentel, T., Pilinis, C., Riipinen, I., Schulz, M., Stohl, A., Swietlicki, E., Vignati, E., Alves, C., Amann, M., Ammann, M., Arabas, S., Artaxo, P., Baars, H., Beddows, D. C. S., Bergström, R., Beukes, J. P., Bilde, M., Burkhart, J. F., Canonaco, F., Clegg, S. L., Coe, H., Crumeyrolle, S., D'Anna, B., Decesari, S., Gilardoni, S., Fischer, M., Fjaeraa, A. M., Fountoukis, C., George, C., Gomes, L., Halloran, P., Hamburger, T., Harrison, R. M., Herrmann, H., Hoffmann, T., Hoose, C., Hu, M., Hyvärinen, A., Hõrrak, U., Iinuma, Y., Iversen, T., Josipovic, M., Kanakidou, M., Kiendler-Scharr, A., Kirkevåg, A., Kiss, G., Klimont, Z., Kolmonen, P., Komppula, M., Kristjánsson, J.-E., Laakso, L., Laaksonen, A., Labonnote, L., Lanz, V. A., Lehtinen, K. E. J., Rizzo, L. V., Makkonen, R., Manninen, H. E., McMeeking, G., Merikanto, J., Minikin, A., Mirme, S., Morgan, W. T., Nemitz, E., O’Donnell, D., Panwar, T. S., Pawlowska, H., Petzold, A., Pienaar, J. J., Pio, C., Plass-Duelmer, C., Prévôt, A. S. H., Pryor, S., Reddington, C. L., Roberts, G., Rosenfeld, D., Schwarz, J., Seland, Ø., Sellegri, K., Shen, X. J., Shiraiwa, M., Siebert, H., Sierau, B., Simpson, D., Sun, J. Y., Topping, D., Tunved, P., Vaattovaara, P., Vakkari, V., Veefkind, J. P., Visschedijk, A., Vuollekoski, H., Vuolo, R., Wehner, B., Wildt, J., Woodward, S., Worsnop, D. R., van Zadelhoff, G.-J., Zardini, A. A., Zhang, K., van Zyl, P. G., Kerminen, V.-M., S Carslaw, K., and Pandis, S. N.: General overview: European Integrated project on Aerosol Cloud Climate and Air Quality interactions (EUCAARI) - integrating aerosol research from nano to global scales, Atmos. Chem. Phys., 11, 13061-13143, doi:10.5194/acp11-13061-2011, 2011.

Lindinger, W., Hansel, A., and Jordan, A.: Proton-transfer-reaction mass spectrometry (PTR-MS): on-line monitoring of volatile organic compounds at pptv levels, Chem. Soc. Rev., 27, 347-354, doi:10.1039/A827347Z 1998.

Liu, P., Ziemann, P. J., Kittelson, D. B., and McMurry, P. H.: Generating Particle Beams of Controlled Dimensions and Divergence: I. Theory of Particle Motion in Aerodynamic Lenses and Nozzle Expansions, Aerosol Sci. Tech., 22, 293-313, doi:10.1080/02786829408959748, 1995a.

Liu, P., Ziemann, P. J., Kittelson, D. B., and McMurry, P. H.: Generating Particle Beams of Controlled Dimensions and Divergence: II. Experimental Evaluation of Particle Motion in Aerodynamic Lenses and Nozzle Expansions, Aerosol Sci. Tech., 22, 314-324, doi:10.1080/02786829408959749, 1995b.

Matthew, B. M., Middlebrook, A. M., and Onasch, T. B.: Collection Efficiencies in an Aerodyne Aerosol Mass Spectrometer as a Function of Particle Phase for Laboratory Generated Aerosols, Aerosol Sci. Tech., 42, 884-898, doi:10.1080/0278682080235679, 2008.

Mensah, A. A., Buchholz, A., Mentel, T. F., Tillmann, R., and Kiendler-Scharr, A.: Aerosol mass spectrometric measurements of stable crystal hydrates of oxalates and inferred relative ionization efficiency of water, J. Aerosol. Sci., 42, 11-19, doi:10.1016/j.jaerosci.2010.10.003, 2011.

Middlebrook, A. M., Bahreini, R., Jimenez, J. L., and Canagaratna, M. R.: Evaluation of Composition-Dependent Collection Efficiencies for the Aerodyne Aerosol Mass Spectrometer using Field Data, Aerosol Sci. Tech., 46, 258-271, doi:10.1080/02786826.2011.620041, 2011.

Monks, P. S., Granier, C., Fuzzi, S., Stohl, A., Williams, M. L., Akimoto, H., Amann, M., Baklanov, A., Baltensperger, U., Bey, I., Blake, N., Blake, R. S., Carslaw, K., Cooper, O. R., Dentener, F., Fowler, D., Fragkou, E., Frost, G. J., Generoso, S., Ginoux, P., Grewe, V., Guenther, A., Hansson, H. C., Henne, S., Hjorth, J., Hofzumahaus, A., Huntrieser, H., Isaksen, I. S. A., Jenkin, M. E., Kaiser, J., Kanakidou, M., Klimont, Z., Kulmala, M., Laj, P., Lawrence, M. G., Lee, J. D., Liousse, C., Maione, M., McFiggans, G., Metzger, A., Mieville, A., Moussiopoulos, N., Orlando, J. J., O’Dowd, C. D., Palmer, P. I., Parrish, D. D., Petzold, A., Platt, U., Pöschl, U., Prévôt, A. S. H., Reeves, C. E., Reimann, S., Rudich, Y., Sellegri, K., Steinbrecher, R., Simpson, D., ten Brink, H., Theloke, J., van der Werf, G. R., Vautard, R., Vestreng, V., Vlachokostas, C., and von Glasow, R.: Atmospheric composition change - global and regional air quality, Atmos. Environ. 43, 5268-5350, doi:10.1016/j.atmosenv.2009.08.021, 2009.

Moolgavkar, S. H., Dockery, D. W., and Pope, C. A.: Air Pollution and Mortality, New Engl. J. Med., 330, 1237-1238, doi:10.1056/NEJM199404283301714, 1994.

Morgan, W. T., Allan, J. D., Bower, K. N., Esselborn, M., Harris, B., Henzing, J. S., Highwood, E. J., Kiendler-Scharr, A., McMeeking, G. R., Mensah, A. A., Northway, M. J., Osborne, S., Williams, P. I., Krejci, R., and Coe, H.: Enhancement of the aerosol direct radiative effect by semi-volatile aerosol components: airborne measurements in North-Western Europe, Atmos. Chem. Phys., 10, 8151-8171, doi:10.5194/acp-10-81512010, 2010a. 
Morgan, W. T., Allan, J. D., Bower, K. N., Highwood, E. J., Liu, D., McMeeking, G. R., Northway, M. J., Williams, P. I., Krejci, R., and Coe, H.: Airborne measurements of the spatial distribution of aerosol chemical composition across Europe and evolution of the organic fraction, Atmos. Chem. Phys., 10, 4065-4083, doi:10.5194/acp-10-4065-2010, 2010b.

Nazarenko, L. and Menon, S.: Varying trends in surface energy fluxes and associated climate between 1960 and 2002 based on transient climate simulations, Geophys. Res. Lett., 32, L22704, doi:10.1029/2005GL023418, 2005.

Nemitz, E., Prévôt, A. S. H., Äijälä, M., Allan, J. D.,, Baltensperger, U., Berresheim, H., Carbone, S., Canagaratna, M. R., Canonaco, F., Capes, G., Ceburnis, D., Choularton, T., Coe, H., Cubison, M. J., Dall'Osto, M., Di Marco, C. F., DeCarlo, P. F., Ehn, M., Eriksson, A., Freney, E., Herrmann, H., Jimenez, J. L., Hildebrandt, L., Juninen, H., Kiendler-Scharr, A., Laaksonen, A., Lanz, V. A., McFiggans, G., Mensah, A. A., Mentel, T. F., Mohr, C., O’Dowd, C., Ortega, A., Ovadnevaite, J., Pagels, J., Pandis, S. N., Phillips, G. J., Poulain, L., Raatikainen, T., Saarikoski, S., Sellegri, K., Spindler, G., Sueper, D., Swietlicki, E., Tiitta, P., and Worsnop, D. R.: European submicron aerosol chemical composition derived from a campaign-based Aerosol Mass Spectrometer network, Atmos. Chem. Phys., in preparation, 2012.

Ng, N. L., Canagaratna, M. R., Zhang, Q., Jimenez, J. L., Tian, J., Ulbrich, I. M., Kroll, J. H., Docherty, K. S., Chhabra, P. S., Bahreini, R., Murphy, S. M., Seinfeld, J. H., Hildebrandt, L., Donahue, N. M., DeCarlo, P. F., Lanz, V. A., Prévôt, A. S. H., Dinar, E., Rudich, Y., and Worsnop, D. R.: Organic aerosol components observed in Northern Hemispheric datasets from Aerosol Mass Spectrometry, Atmos. Chem. Phys., 10, 46254641, doi:10.5194/acp-10-4625-2010, 2010.

Nober, F. J., Graf, H.-F., and Rosenfeld, D.: Sensitivity of the global circulation to the suppression of precipitation by anthropogenic aerosols, Global Planet. Change, 37, 57-80, doi:10.1016/S09218181(02)00191-1, 2003.

Norris, J. R. and Wild, M.: Trends in aerosol radiative effects over Europe inferred from observed cloud cover, solar "dimming" and solar "brightening", J. Geophys. Res., 112, D08214, doi:10.1029/2006JD007794, 2007.

Phillips, V. T. J., Choularton, T. W., Blyth, A. M., and Latham, J.: The influence of aerosol concentrations on the glaciation and precipitation of a cumulus cloud, Q. J. Roy. Meteorol. Soc., 128, 951-971, doi:10.1256/0035900021643601, 2002.

Pope, C. A., Burnett, R. T., Thun, M. J., Calle, E. E., Krewski, D., Ito, K., and Thurston, G. D.: Lung Cancer, Cardiopulmonary Mortality, and Long-term Exposure to Fine Particulate Air Pollution, J. Am. Med. Assoc., 287, 1132-1141, doi:10.1001/jama.287.9.1132, 2002.

Poulain, L., Spindler, G., Birmili, W., Plass-Dülmer, C., Wiedensohler, A., and Herrmann, H.: Seasonal and diurnal variations of particulate nitrate and organic matter at the IfT research station Melpitz, Atmos. Chem. Phys., 11, 12579-12599, doi:10.5194/acp-11-12579-2011, 2011.

Putaud, J.-P., Raes, F., Van Dingenen, R., Brüggemann, E., Facchini, M. C., Decesari, S., Fuzzi, S., Gehrig, R., Hüglin, C., Laj, P., Lorbeer, G., Maenhaut, W., Mihalopoulos, N., Müller, K., Querol, X., Rodriguez, S., Schneider, J., Spindler, G., ten Brink, H., Tørseth, K., and Wiedensohler, A.: A European aerosol phenomenology-2: chemical characteristics of particulate matter at kerbside, urban, rural and background sites in Europe, Atmos. Environ., 38, 2579-2595, doi:10.1016/j.atmosenv.2004.01.041, 2004.

Quinn, P. K., Bates, T. S., Coffman, D., Onasch, T. B., Worsnop, D. R., Baynard, T., de Gouw, J. A., Goldan, P. D., Kuster, W. C., Williams, E., Roberts, J. M., Lemer, B., Stohl, A., Pettersson, A., and Lovejoy, E. R.: Impacts of sources and aging on submicrometer aerosol properties in the marine boundary layer across the Gulf of Maine, J. Geophys. Res., 111, D23S36, doi:10.1029/2006JD007582, 2006.

Ramanathan, V., Li, F., Ramana, M. V., Praveen, P. S., Kim, D., Corrigan, C. E., Nguyen, H., Stone, E. A., Schauer, J. J., Carmichael, G. R., Adhikary, B., and Yoon, S. C.: Atmospheric brown clouds: Hemispherical and regional variations in long-range transport, absorption, and radiative forcing, J. Geophys. Res., 112, D22S21, doi:10.1029/2006JD008124, 2007.

Roelofs, G. J., ten Brink, H., Kiendler-Scharr, A., de Leeuw, G., Mensah, A., Minikin, A., and Otjes, R.: Evaluation of simulated aerosol properties with the aerosol-climate model ECHAM5HAM using observations from the IMPACT field campaign, Atmos. Chem. Phys., 10, 7709-7722, doi:10.5194/acp-10-77092010, 2010.

Rogge, W. F., Mazurek, M. A., Hildemann, L. M., Cass, G. R., and Simoneit, B. R. T.: Quantification of urban organic aerosols at a molecular level: Identification, abundance and seasonal variation, Atmos. Environ., 27, 1309-1330, doi:10.1016/09601686(93)90257-Y, 1993.

Romanou, A., Liepert, B., Schmidt, G. A., Rossow, W. B., Ruedy, R. A., and Zhang, Y.: 20th century changes in surface solar irradiance in simulations and observations, Geophys. Res. Lett., 34, L05713, doi:10.1029/2006GL028356, 2007.

Rotz, C. A.: Management to reduce nitrogen losses in animal production, J. Anim. Sci., 82, E119-137, 2004.

Russchenberg, H., Bosveld, F., Swart, D., ten Brink, H., de Leeuw, G., Uijlenhoet, R., Arbesser-Rastburg, B., van der Marel, H., Ligthart, L., Boers, R., and Apituley, A.: Ground-Based Atmospheric Remote Sensing in the Netherlands: European Outlook, The Institute of Electronics, Information and Communication Engineers, E88-B, 2005.

Schaap, M., Otjes, R. P., and Weijers, E. P.: Illustrating the benefit of using hourly monitoring data on secondary inorganic aerosol and its precursors for model evaluation, Atmos. Chem. Phys., 11, 11041-11053, doi:10.5194/acp-11-11041-2011, 2011.

Slanina, J., ten Brink, H. M., Otjes, R. P., Even, A., Jongejan, P., Khlystov, A., Waijers-Ijpelaan, A., Hu, M., and Lu, Y.: The continuous analysis of nitrate and ammonium in aerosols by the steam jet aerosol collector (SJAC): extension and validation of the methodology, Atmos. Environ., 35, 2319-2330, doi:10.1016/S1352-2310(00)00556-2, 2001.

Tao, W. K., Li, X. W., Khain, A., Matsui, T., Lang, S., and Simpson, J.: Role of atmospheric aerosol concentration on deep convective precipitation: Cloud-resolving model simulations, J. Geophys. Res., 112, D24S18, doi:10.1029/2007JD008728, 2007.

ten Brink, H. M., Plomp, A., Spoelstra, H., and van de Vate, J. F.: A high-resolution electrical mobility aerosol spectrometer (MAS), J. Aerosol Sci., 14, 589-597, doi:10.1016/0021-8502(83)900642, 1983.

ten Brink, H., Kruisz, C., Kos, G. P. A., and Berner, A.: Composition/size of the light-scattering aerosol in the Netherlands, 
Atmos. Environ., 31, 3955-3962, doi:10.1016/S13522310(97)00232-X, 1997.

ten Brink, H., Otjes, R., Jongejan, P., and Slanina, S.: An instrument for semi-continuous monitoring of the size-distribution of nitrate, ammonium, sulphate and chloride in aerosol, Atmos. Environ., 41, 2768-2779, doi:10.1016/j.atmosenv.2006.11.041, 2007.

ten Brink, H., Otjes, R., Jongejan, P., and Kos, G.: Monitoring of the ratio of nitrate to sulphate in size-segregated submicron aerosol in the Netherlands, Atmos. Res., 92, 270-276, doi:10.1016/j.atmosres.2008.12.003, 2009.

Trebs, I., Meixner, F. X., Slanina, J., Otjes, R., Jongejan, P., and Andreae, M. O.: Real-time measurements of ammonia, acidic trace gases and water-soluble inorganic aerosol species at a rural site in the Amazon Basin, Atmos. Chem. Phys., 4, 967-987, doi:10.5194/acp-4-967-2004, 2004.

Van Dingenen, R., Raes, F., Putaud, J.-P., Baltensperger, U., Charron, A., Facchini, M. C., Decesari, S., Fuzzi, S., Gehrig, R., Hansson, H.-C., Harrison, R. M., Hüglin, C., Jones, A. M., Laj, P., Lorbeer, G., Maenhaut, W., Palmgren, F., Querol, X., Rodriguez, S., Schneider, J., Brink, H. t., Tunved, P., Tørseth, K., Wehner, B., Weingartner, E., Wiedensohler, A., and Wåhlin, P.: A European aerosol phenomenology - 1: physical characteristics of particulate matter at kerbside, urban, rural and background sites in Europe, Atmos. Environ., 38, 2561-2577, doi:10.1016/j.atmosenv.2004.01.040, 2004.

Van Krevelen, D. W.: Graphical-statistical method for the study of structure and reaction processes of coal, Fuel, 24, 269-284, 1950.

Weijers, E. P., Schaap, M., Nguyen, L., Matthijsen, J., Denier van der Gon, H. A. C., ten Brink, H. M., and Hoogerbrugge, R.: Anthropogenic and natural constituents in particulate matter in the Netherlands, Atmos. Chem. Phys., 11, 2281-2294, doi:10.5194/acp-11-2281-2011, 2011.

Wiedensohler, A.: An approximation of the bipolar charge distribution for particles in the submicron size range, J. Aerosol Sci., 19, 387-389, doi:10.1016/0021-8502(88)90278-9, 1988.

Wiedensohler, A., Birmili, W., Nowak, A., Sonntag, A., Weinhold, K., Merkel, M., Wehner, B., Tuch, T., Pfeifer, S., Fiebig, M., Fjäraa, A. M., Asmi, E., Sellegri, K., Depuy, R., Venzac, H., Villani, P., Laj, P., Aalto, P., Ogren, J. A., Swietlicki, E., Williams, P., Roldin, P., Quincey, P., Hüglin, C., Fierz-Schmidhauser, R., Gysel, M., Weingartner, E., Riccobono, F., Santos, S., Grüning, C., Faloon, K., Beddows, D., Harrison, R., Monahan, C., Jennings, S. G., O’Dowd, C. D., Marinoni, A., Horn, H. G., Keck,
L., Jiang, J., Scheckman, J., McMurry, P. H., Deng, Z., Zhao, C. S., Moerman, M., Henzing, B., de Leeuw, G., Löschau, G., and Bastian, S.: Mobility particle size spectrometers: harmonization of technical standards and data structure to facilitate high quality long-term observations of atmospheric particle number size distributions, Atmos. Meas. Tech., 5, 657-685, doi:10.5194/amt5-657-2012, 2012.

Williams, B. J., Goldstein, A. H., Kreisberg, N. M., and Hering, S. V.: An In-Situ Instrument for Speciated Organic Composition of Atmospheric Aerosols: Thermal Desorption Aerosol GC/MS-FID (TAG), Aerosol Sci. Tech., 40, 627-638, doi:10.1080/02786820600754631, 2006.

Zhang, Q., Alfarra, M. R., Worsnop, D. R., Allan, J. D., Coe, H., Canagaratna, M. R., and Jimenez, J. L.: Deconvolution and Quantification of Hydrocarbon-like and Oxygenated Organic Aerosols Based on Aerosol Mass Spectrometry, Environ. Sci. Technol., 39, 4938-4952, doi:10.1021/es0485681, 2005a.

Zhang, Q., Worsnop, D. R., Canagaratna, M. R., and Jimenez, J. L.: Hydrocarbon-like and oxygenated organic aerosols in Pittsburgh: insights into sources and processes of organic aerosols, Atmos. Chem. Phys., 5, 3289-3311, doi:10.5194/acp-5-32892005, 2005b

Zhang, Q., Jimenez, J. L., Canagaratna, M. R., Allan, J. D., Coe, H., Ulbrich, I., Alfarra, M. R., Takami, A., Middlebrook, A. M., Sun, Y. L., Dzepina, K., Dunlea, E., Docherty, K., DeCarlo, P. F., Salcedo, D., Onasch, T., Jayne, J. T., Miyoshi, T., Shimono, A., Hatakeyama, S., Takegawa, N., Kondo, Y., Schneider, J., Drewnick, F., Borrmann, S., Weimer, S., Demerjian, K., Williams, P., Bower, K., Bahreini, R., Cottrell, L., Griffin, R. J., Rautiainen, J., Sun, J. Y., Zhang, Y. M., and Worsnop, D. R.: Ubiquity and dominance of oxygenated species in organic aerosols in anthropogenically-influenced Northern Hemisphere midlatitudes, Geophys. Res. Lett., 34, L13801, doi:10.1029/2007GL029979, 2007.

Zhang, X., Smith, K. A., Worsnop, D. R., Jimenez, J. L., Jayne, J. T., Kolb, C. E., Morris, J., and Davidovits, P.: Numerical Characterization of Particle Beam Collimation: Part II Integrated Aerodynamic-Lens-Nozzle System, Aerosol Sci. Tech., 38, 619638, doi:10.1080/02786820490479833, 2004. 